\title{
Wildfires in northern Eurasia affect the budget of black carbon in the Arctic - a 12-year retrospective synopsis (2002-2013)
}

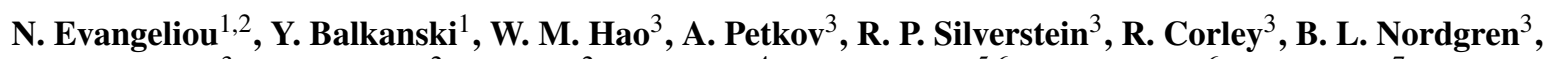

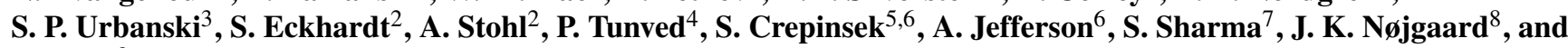 \\ H. Skov ${ }^{8}$ \\ ${ }^{1}$ CEA-UVSQ-CNRS UMR 8212, Laboratoire des Sciences du Climat et de l'Environnement (LSCE), \\ Institut Pierre et Simon Laplace, L'Orme des Merisiers, 91191 Gif sur Yvette Cedex, France \\ ${ }^{2}$ Norwegian Institute for Air Research (NILU), Department of Atmospheric and Climate Research (ATMOS), Kjeller, Norway \\ ${ }^{3}$ Missoula Fire Sciences Laboratory, Rocky Mountain Research Station, United States Forest Service, \\ Missoula, Montana, USA \\ ${ }^{4}$ Department of Applied Environmental Science, Stockholm University, Stockholm, Sweden \\ ${ }^{5}$ Cooperative Institute for Research in Environmental Sciences, University of Colorado, Boulder, Colorado, USA \\ ${ }^{6}$ NOAA Earth System Research Laboratory Physical Sciences Division/Polar Observations \& Processes, \\ Boulder, Colorado, USA \\ ${ }^{7}$ Climate Research Division, S\&T Branch, Environment Canada, Toronto, Ontario, Canada \\ ${ }^{8}$ Department of Environmental Science, Aarhus University, 4000 Roskilde, Denmark
}

Correspondence to: N. Evangeliou (nikolaos.evangeliou@ nilu.no)

Received: 9 December 2015 - Published in Atmos. Chem. Phys. Discuss.: 8 February 2016

Revised: 5 May 2016 - Accepted: 27 May 2016 - Published: 21 June 2016

\begin{abstract}
In recent decades much attention has been given to the Arctic environment, where climate change is happening rapidly. Black carbon (BC) has been shown to be a major component of Arctic pollution that also affects the radiative balance. In the present study, we focused on how vegetation fires that occurred in northern Eurasia during the period of 2002-2013 influenced the budget of BC in the Arctic. For simulating the transport of fire emissions from northern Eurasia to the Arctic, we adopted BC fire emission estimates developed independently by GFED3 (Global Fire Emissions Database) and FEI-NE (Fire Emission Inventory - northern Eurasia). Both datasets were based on fire locations and burned areas detected by MODIS (Moderate resolution Imaging Spectroradiometer) instruments on NASA's (National Aeronautics and Space Administration) Terra and Aqua satellites. Anthropogenic sources of BC were adopted from the MACCity (Monitoring Atmospheric Composition and Climate and megacity Zoom for the Environment) emission inventory.

During the 12-year period, an average area of $250000 \mathrm{~km}^{2} \mathrm{yr}^{-1}$ was burned in northern Eurasia (FEI-
\end{abstract}

$\mathrm{NE}$ ) and the global emissions of $\mathrm{BC}$ ranged between 8.0 and $9.5 \mathrm{Tg} \mathrm{yr}^{-1}$ (FEI-NE+MACCity). For the BC emitted in the Northern Hemisphere (based on FEI-NE+MACCity), about $70 \%$ originated from anthropogenic sources and the rest from biomass burning (BB). Using the FEI-NE+MACCity inventory, we found that $102 \pm 29 \mathrm{kt} \mathrm{yr}^{-1} \mathrm{BC}$ was deposited in the Arctic (defined here as the area north of $67^{\circ} \mathrm{N}$ ) during the 12 years simulated, which was twice as much as when using the MACCity inventory $\left(56 \pm 8 \mathrm{kt} \mathrm{yr}^{-1}\right)$. The annual mass of BC deposited in the Arctic from all sources (FEI-NE in northern Eurasia, MACCity elsewhere) is significantly higher by about $37 \%$ in 2009 ( 78 vs. $57 \mathrm{kt} \mathrm{yr}^{-1}$ ) to $181 \%$ in 2012 (153 vs. $\left.54 \mathrm{kt} \mathrm{yr}^{-1}\right)$, compared to the BC deposited using just the MACCity emission inventory. Deposition of $\mathrm{BC}$ in the Arctic from BB sources in the Northern Hemisphere thus represents $68 \%$ of the BC deposited from all BC sources (the remaining being due to anthropogenic sources). Northern Eurasian vegetation fires (FEI-NE) contributed $85 \%$ (79-91\%) to the BC deposited over the Arctic from all BB sources in the Northern Hemisphere. 
We estimate that about $46 \%$ of the $\mathrm{BC}$ deposited over the Arctic from vegetation fires in northern Eurasia originated from Siberia, $6 \%$ from Kazakhstan, $5 \%$ from Europe, and about $1 \%$ from Mongolia. The remaining $42 \%$ originated from other areas in northern Eurasia. About $42 \%$ of the $\mathrm{BC}$ released from northern Eurasian vegetation fires was deposited over the Arctic (annual average: $17 \%$ ) during spring and summer.

\section{Introduction}

The Arctic environment has experienced rapid modifications (e.g. warming, ice degradations) during the last four decades and concerns have been raised that human activities were the main cause for these transformations. The thinning of Arctic sea ice (Hansen and Nazarenko, 2004) and the Arctic's rapidly growing human influence (e.g. transportation, drilling, industry) indicates the need not only for further decrease of greenhouse emissions, but also a better understanding of aerosol properties, as well as of aerosol interaction with radiation, clouds, and ecosystems in polar regions. The "Arctic haze" phenomenon in winter and spring is a major feature of Arctic air pollution. Several studies have been conducted to determine the sources of Arctic air pollution using trajectory, regional, and global models (e.g. Hirdman et al., 2010a; Klonecki et al., 2003; Koch and Hansen, 2005; Law and Stohl, 2007; Stohl, 2006). They all agree that the majority of the pollution in the high-latitude Arctic, especially near the surface, originates at mid- and high-latitudes, and that the accumulation of pollution in the Arctic is a consequence of the slow removal processes in winter and spring (Shaw, 1995). Also, northern Eurasia (Europe, Siberia, Kazakhstan, Mongolia, etc.) is the main source of the Arctic BC due to both wildfire and anthropogenic emissions.

Episodic emissions from mid- and high-latitude vegetation fires can affect tropospheric concentrations of trace gases (e.g. carbon monoxide $(\mathrm{CO})$, ozone $\left(\mathrm{O}_{3}\right)$, volatile organic compounds (VOC), and aerosols (e.g. BC)) several thousand kilometres away from the sources (Forster et al., 2001; Wotawa and Trainer, 2000). Additionally, emissions from boreal fires lifted by convection can substantially alter upper tropospheric and the lowermost stratospheric radiation balance and chemistry (Waibel et al., 1999; Jost et al., 2004; Fromm et al., 2005). Aerosols and trace gases are uplifted during transport to the Arctic due to the upward-sloping surfaces of constant potential temperature towards the Arctic (Klonecki et al., 2003; Stohl, 2006). However, understanding of aerosol transport from midlatitudes to the Arctic has been limited because of the lack of quantification of the relevant aerosol sources and removal processes.

Globally, BC contributed to climate warming with recent estimates of radiative forcing at the top of the atmosphere ranging between 0.17 and $0.71 \mathrm{~W} \mathrm{~m}^{-2}$ (Bond et al., 2013;
Myhre et al., 2013; Wang et al., 2014). Snow albedo may be reduced by $1-3 \%$ in fresh snow by $\mathrm{BC}$ deposited in the Arctic and by another factor of 3 as snow ages and the $\mathrm{BC}$ becomes more concentrated (Clarke and Noone, 1985). Hansen and Nazarenko (2004) found that the decreased albedo in Arctic snow and ice since preindustrial times resulted in a hemispheric radiative forcing of $+0.3 \mathrm{~W} \mathrm{~m}^{-2}$, which may have had a substantial impact on the climate in the Northern Hemisphere, while for northern Russia it amounts to $0.2 \mathrm{~W} \mathrm{~m}^{-2}$ (Lee et al., 2013a, b). Airborne soot also absorbs incoming solar radiation, thus warming the air and reducing tropical cloudiness (Ackerman et al., 2000).

Biomass burning (BB) constitutes a major source of $\mathrm{BC}$, in addition to incomplete combustion of fossil fuels (primarily coal and diesel) and burning of biofuels. BC is the most absorbing portion of carbonaceous aerosols, commonly referred to as soot. BC deposited on snow/ice surfaces reduces surface reflectance and can promote faster melting of snow/ice in the Arctic, which is tightly coupled to climate effects through snow-albedo feedback (Flanner et al., 2007, 2009; Hansen and Nazarenko, 2004). In addition, high aerosol concentrations in the Arctic haze lead to the enhancement of cloud longwave emissivity (Garrett and Zhao, 2006; Lubin and Vogelmann, 2006), leading to surface warming and accelerating the melting of snow/ice.

Model simulations by Stohl (2006) suggested that the contributions from BB to Arctic BC loadings, particularly from fires in Siberia, exceeded the anthropogenic contributions in the summer. Moreover, large amounts of BC from Siberia and Kazakhstan have been observed during aircraft campaigns over Alaska in spring 2008 (Warneke et al., 2009), which was a year with an unusually early start of the BB season in northern Eurasia. Warneke et al. (2010) estimated that BB in Russia may have doubled aerosol concentrations in the Arctic haze during the spring. $\mathrm{BC}$ has been monitored at several surface stations in the Arctic (e.g. Alert in Canada, Barrow in Alaska, and Janiskoski in Russia) for many years (e.g. Sirois and Barrie, 1999; Sharma et al., 2006; Quinn et al., 2008; Eleftheriadis et al., 2009; Gong et al., 2010; Huang et al., 2010; and many others), showing decreasing trends during the 1980s and 1990s, which have been attributed to reductions in anthropogenic emissions (Sharma et al., 2013; Hirdman et al., 2010b).

In this study, we focused on the transport of BC produced by vegetation fires in northern Eurasia to the Arctic from 2002 to 2013 . We define northern Eurasia from $10^{\circ} \mathrm{W}$ to $170^{\circ} \mathrm{E}$ and 35 to $80^{\circ} \mathrm{N}$. The Arctic is defined here as the area north of the Arctic Circle $\left(\sim 67^{\circ} \mathrm{N}\right)$. Fires were mapped using satellite measurements from MODIS on NASA's Terra and Aqua satellites. We investigated the geographic distribution of $\mathrm{BC}$ sources contributing to the Arctic $\mathrm{BC}$ budget, which needed to be better understood for developing $\mathrm{BC}$ mitigation policies. Moreover, the transport of $\mathrm{BC}$ to the Arctic after vegetation fires was defined as transport efficiency of BC. Shindell et al. (2008) showed large differences in the 
calculated BC concentrations in the Arctic using different General Circulation Models (GCMs). A large part of these differences was attributed to the different model treatments of $\mathrm{BC}$ aging from hydrophobic to hydrophilic and to rainout/washout processes during transport. It indicated the necessity of a continuously improving description of BC transport in order to better assess the impact on the Arctic climate despite many recent improvements (e.g. Browse et al., 2012; Eckhardt et al., 2015).

This paper consists of five sections. The methodology (transport model, model set-up, emission altitude, satellitederived BC emissions) is discussed in detail in the next section. The results, with respect to Arctic transport and deposition of BC, are presented in Sect. 3. Then, we show how different regions in northern Eurasia contribute to the Arctic $\mathrm{BC}$, distinguishing between anthropogenic and BB sources (Sect. 3.3). In Sect. 4.1, we discuss how our modelling results compare to observations of BC using data from five different Arctic stations for the period of our simulations (20022013). Finally, we calculate and study transport efficiencies of $\mathrm{BC}$ to the Arctic from different $\mathrm{BB}$ regions (Sect. 4.2). The main conclusions are presented in Sect. 5.

\section{Methodology}

\subsection{The LMDz-OR-INCA model}

We used the LMDz-OR-INCA global chemistry-aerosolclimate model, which couples the LMDz (Laboratoire de Météorologie Dynamique) GCM (Hourdin et al., 2006) and the INCA (INteraction with Chemistry and Aerosols) model (Hauglustaine et al., 2004). The interaction between the atmosphere and the land surface was ensured through the coupling of LMDz with the ORCHIDEE (ORganizing Carbon and Hydrology In Dynamic Ecosystems) dynamical vegetation model (Krinner et al., 2005). In the present configuration, the model included 39 hybrid vertical levels extending to the stratosphere and a horizontal resolution of $1.29^{\circ} \times 0.94^{\circ}(280$ grid cells in longitude, 192 in latitude $)$. A more detailed description and an extended evaluation of the GCM can be found in Hourdin et al. (2006). The large-scale advection of tracers was calculated based on a monotonic finite-volume second-order scheme (Hourdin and Armengaud, 1999). Deep convection was parameterized according to the scheme of Emanuel (1991). The turbulent mixing in the planetary boundary layer (PBL) was based on a local secondorder closure formalism.

A comparison made with inert tracers indicated an enhanced vertical transport as the horizontal resolution of the model was increased from $144 \times 142$ grid points to $280 \times 192$. We have studied the effect of the model resolution on the robustness of the predicted $\mathrm{BC}$ concentration distribution in Wang et al. (2014). The higher model resolution and an updated emission inventory used in this work allowed for substantially improving the correlation between predicted and measured $\mathrm{BC}$ concentrations. The vertical profiles of $\mathrm{BC}$ over the Arctic measured during the ARCTAS campaigns (Arctic Research of the Composition of the Troposphere from Aircraft and Satellites) were used to assess the ability of such a model to represent the vertical distribution of BC. The comparison showed that BC loads over the Arctic were slightly underestimated for the time of the ARCTAS flights. The model was also compared to other models in the recent AeroCom Phase II intercomparison (Myhre et al., 2013). The global mean anthropogenic all-sky and clearsky aerosol radiative forcing is slightly more negative than the median for all the models $\left(-0.36 \mathrm{vs} .-0.27 \mathrm{~W} \mathrm{~m}^{-2}\right)$ and the BC load from fossil fuel and biofuel emissions is very close to the corresponding median of the models ( 0.15 vs. $0.14 \mathrm{mg} \mathrm{m}^{-2}$ ).

The INCA model simulates the distribution of anthropogenic aerosols such as sulfates, nitrate $\left(\mathrm{NO}_{3}\right), \mathrm{BC}$, and particulate organic matter (POM), as well as natural aerosols such as sea salt and dust. The aerosol model keeps track of both the number and the mass of aerosols using a modal approach to treat the size distribution, which is described by a superposition of 5 log-normal modes (Schulz, 2007), each with a fixed spread. To treat the optically relevant aerosol size diversity, particle modes were categorized in three ranges: submicronic (diameter $<1 \mu \mathrm{m}$ ), corresponding to the accumulation mode; micronic (diameter $1-10 \mu \mathrm{m}$ ), corresponding to coarse particles; and super-micronic or super coarse particles (diameter $>10 \mu \mathrm{m})$. Compared to a bin-scheme, the treatment of the size distribution with modes was computationally much more efficient (Schulz et al., 1998). Furthermore, to account for the diversity in chemical composition, hygroscopicity, and mixing state, we distinguished between soluble and insoluble modes. In both submicron and micron size ranges, soluble and insoluble aerosols were treated separately. Sea salt, $\mathrm{SO}_{4}$, and methane sulfonic acid (MSA) were treated as soluble components of the aerosol, dust was treated as insoluble, whereas nitrate, BC, and POM appeared both in the soluble and insoluble fractions. The aging of primary insoluble carbonaceous particles transfers insoluble aerosol number and mass to soluble ones with a half-life of 1.1 days (Chung and Seinfeld, 2002). The deposition scheme used in the model is described in detail in Evangeliou et al. (2013).

\subsection{Model set-up, BC inventories, and injection height}

The simulations lasted from 1 January 2002 to 31 December 2013. The model ran in a nudged mode using 6-hourly ERA Interim Re-analysis data (ECMWF, 2014) with a relaxation time of 10 days (Hourdin and Issartel, 2000).

To support the IPCC-AR5 (Intergovernmental Panel for Climate Change Assessment Report 5) and the ACCMIP (Atmospheric Chemistry and Climate Model Intercomparison Project), a historical emissions dataset was developed (Lamarque et al., 2010) on a decadal basis (from 1850 to 
2000 for the historical dataset), as well as RCP (Representation Concentration Pathway) emission scenarios for the period after the year 2000. As part of a project funded by the European Commission, MACC (Monitoring Atmospheric Composition and Climate) and CityZen (megacity Zoom for the Environment), the ACCMIP and the RCP emissions datasets were adapted and extended to the year 2013 on a yearly basis. For anthropogenic emissions, emission data were interpolated on a yearly basis. For BB emissions, the ACCMIP dataset was extended to yearly and monthly mean calculated from modified RETRO (REanalysis of the TROposhperic chemical composition) BC emission data for the years 1980 to 1996, and from GFEDv3 carbon emission data for the years 1997 to 2013 by applying a single set of vegetation-type-specific emission factors, and the predominant vegetation map used in the GFEDv3 inventory. This extension of the ACCMIP and RCP emission dataset for the MACC and CityZEN projects is referred to as MACCity (MACC/CityZen) emission dataset (Granier et al., 2011). As it is explained below, emissions of MACCity (anthropogenic and $\mathrm{BB}$ ) were used as the input source of the model worldwide, in which BB sources were derived from GFEDv3. In addition, we adopted $\mathrm{BC}$ emissions from $\mathrm{BB}$ in northern Eurasia from 2002 to 2013 (FEI-NE) described in the companion paper (Hao et al., 2016), while MACCity emissions were used for all the sources in other regions and for anthropogenic sources in northern Eurasia.

Injection height is a key factor that controls transport and in turn deposition of $\mathrm{BC}$ emitted from fires. It is generally accepted that only explosive volcanic eruptions and strong crown fires (more common in North America than in northern Eurasia) have the energy to inject pollutants from the surface into the stratosphere (Jost et al., 2004; Fromm et al., 2005). In a modelling study of midlatitude supercell thunderstorms (Wang, 2003), it was reported that these plumes could induce important transport into the lowermost stratosphere. These findings suggest that extreme convection, even unassociated with energetic forest fires, may represent an important pathway for rapid, efficient redistribution of gases and particles from the lowest levels of the atmosphere to the lower stratosphere or, more commonly, to the upper troposphere. Nedelec et al. (2005) described such a case for a fire happening over Siberia. However, injection of emissions in the lower troposphere is more common. Recently, Sofiev et al. (2013) published global maps of emission heights of wildfires that occurred between 2000 and 2012, reporting that about $80 \%$ of the smoke is generally injected within the PBL, while the rest is injected at higher altitudes. Here we follow the same pattern as Sofiev et al. (2013) for northern Eurasia, where $90 \%$ of the emissions were injected below $1.1 \mathrm{~km}$, with the rest in heights up to $1.5 \mathrm{~km}$. Outside Eurasia, a similar injection profile is followed with $100 \%$ of the emissions occurring up to $1 \mathrm{~km}$.

\subsection{BC emissions from FEI-NE and MACCity}

For the 12-year global simulations, anthropogenic sources of $\mathrm{BC}$ were adopted from the MACCity emission database. With regards to BB emissions, MACCity BB emissions from GFED3 were applied for all the regions outside northern Eurasia, while within northern Eurasia anthropogenic emissions from MACCity and BB from FEI-NE (Hao et al., 2016) were adopted. In summary, $B C$ emissions from $B B$ in northern Eurasia, excluding agricultural fires, were estimated based on the area burned, fuel loading, percentage of the fuel burned, and emission factors of $\mathrm{BC}$ from different vegetation types (Hao et al., 2016).

This combined simulation is hereafter referred to as FEINE+MACCity. For comparison, we carried out the same simulation but using MACCity emissions alone (i.e. BB emissions in northern Eurasia were also taken from MACCity) for the same period (2002-2013) (from now on referred to it as MACCity simulation). The different simulations are shown in Table 1.

\subsection{Lifetime calculations}

Several definitions for atmospheric lifetime exist. In any domain of the Earth's atmosphere the mass balance can be expressed as follows:

$\frac{\mathrm{d} B(t)}{\mathrm{d} t}=S(t)-\frac{B(t)}{\tau(t)}$,

where $B(t)$ is the atmospheric burden, $S(t)$ is the mass entering or exiting the domain and $\tau(t)$ is the removal time over a given time step. If one assumes equilibrium between $S(t)$ and deposition (steady state conditions), the mean steady state lifetime will be the following:

$\tau_{\mathrm{ss}}=\frac{\bar{B}}{\bar{D}}$,

where $\bar{B}$ and $\bar{D}$ are the mean atmospheric burden and deposition over a specific period (Croft et al., 2014).

\subsection{Observation data}

With different types of instruments, we collected measurements of BC, which may not always be directly comparable. Following the nomenclature of Petzold et al. (2013), we referred to measurements based on light absorption as equivalent $\mathrm{BC}(\mathrm{eBC})$ and measurements based on thermal-optical methods as elemental carbon (EC).

Aerosol light absorption data were obtained from five sites in different parts of the Arctic: Alert, Canada $\left(62.3^{\circ} \mathrm{W}\right.$, $82.5^{\circ} \mathrm{N} ; 210 \mathrm{~m}$ a.s.1.), Barrow, Alaska $\left(156.6^{\circ} \mathrm{W}, 71.3^{\circ} \mathrm{N}\right.$; 11 ma.s.l.), Zeppelin/Ny Ålesund, Spitsbergen, Norway $\left(11.9^{\circ} \mathrm{E}, 78.9^{\circ} \mathrm{N} ; 478 \mathrm{~m}\right.$ a.s.l.), and Tiksi, Russia $\left(128.9^{\circ} \mathrm{E}\right.$, $1571.6^{\circ} \mathrm{N} ; 1 \mathrm{~m}$ a.s.l.). Different types of particle soot absorption photometers (PSAPs) were used for the measurements at Barrow and Zeppelin, and an aethalometer was 
Table 1. List of simulations from this study to characterize the transport and origin of BC.

\begin{tabular}{|c|c|c|c|}
\hline Name & Anthropogenic sources & BB sources & Purpose \\
\hline FEI-NE+MACCity & MACCity & FEI-NE & Study of BC transport to the Arctic \\
\hline MACCity & MACCity & MACCity & Comparison with the combined FEI-NE+MACCity run \\
\hline Europe & - & FEI-NE & $\begin{array}{l}\text { Study of BC originating from Europe by masking this } \\
\text { region }\end{array}$ \\
\hline Asia & - & FEI-NE & $\begin{array}{l}\text { Study of BC originating from Asia by masking this re- } \\
\text { gion }\end{array}$ \\
\hline Siberia & - & FEI-NE & $\begin{array}{l}\text { Study of BC originating from Siberia by masking this } \\
\text { region }\end{array}$ \\
\hline Kazakhstan & - & FEI-NE & $\begin{array}{l}\text { Study of BC originating from Kazakhstan by masking } \\
\text { this region }\end{array}$ \\
\hline Mongolia & - & FEI-NE & $\begin{array}{l}\text { Study of BC originating from Mongolia by masking this } \\
\text { region }\end{array}$ \\
\hline $35-40^{\circ} \mathrm{N}\left(10^{\circ} \mathrm{W}-170^{\circ} \mathrm{E}\right)$ & - & FEI-NE & $\begin{array}{l}\text { Study of } \mathrm{BC} \text { originating from latitudes } 30 \text { to } 40^{\circ} \mathrm{N} \text { in } \\
\text { Eurasia by masking this region }\end{array}$ \\
\hline $40-50^{\circ} \mathrm{N} \quad\left(10-170^{\circ} \mathrm{E}\right)$ & - & FEI-NE & $\begin{array}{l}\text { Study of } \mathrm{BC} \text { originating from latitudes } 40 \text { to } 50^{\circ} \mathrm{N} \text { in } \\
\text { Eurasia by masking this region }\end{array}$ \\
\hline $50-60^{\circ} \mathrm{N}\left(10^{\circ} \mathrm{W}-170^{\circ} \mathrm{E}\right)$ & & FEI-NE & $\begin{array}{l}\text { Study of } \mathrm{BC} \text { originating from latitudes } 50 \text { to } 60^{\circ} \mathrm{N} \text { in } \\
\text { Eurasia by masking this region }\end{array}$ \\
\hline $60-90^{\circ} \mathrm{N}\left(10^{\circ} \mathrm{W}-170^{\circ} \mathrm{E}\right)$ & - & FEI-NE & $\begin{array}{l}\text { Study of BC originating from latitudes }>60^{\circ} \mathrm{N} \text { in Eura- } \\
\text { sia by masking this region }\end{array}$ \\
\hline
\end{tabular}

used at Alert and Tiksi. All these instruments measured the particle light absorption coefficient $\sigma_{\text {ap }}$, each at their own specific wavelength (typically at around $530-550 \mathrm{~nm}$ ), and for different size fractions of the aerosol (typically particles smaller than $1,2.5$, or $10 \mu \mathrm{m}$ are sampled at different humidities). Conversion of $\sigma_{\mathrm{ap}}$ to eBC mass concentrations is not straightforward and requires certain assumptions (Petzold et al., 2013). The mass absorption efficiency used for conversion can be specific to a site and is uncertain by at least a factor of two. For Tiksi, the conversion was done internally by the aethalometer. For the other sites, a mass absorption efficiency of $10 \mathrm{~m}^{2} \mathrm{~g}^{-1}$, typical of aged $\mathrm{BC}$ aerosol (Bond and Bergstrom, 2006), was used. Sharma et al. (2013) used an even higher value of $19 \mathrm{~m}^{2} \mathrm{~g}^{-1}$ for Barrow and $10 \mathrm{~m}^{2} \mathrm{~g}^{-1}$ for Alert data.

At Villum Research Station, Station Nord, Greenland, thermal-optical measurements were available. Weekly aerosol samples were analysed with a thermal-optical Lab OC / EC instrument from Sunset Laboratory Inc (Tigard, OR, USA). Punches of $2.5 \mathrm{~cm}^{2}$ were cut from the filters sampled at Villum and analysed according to the EUSAAR-2 protocol (Cavalli et al., 2010).

At Alert, eBC data were available for the years 20062013, at Barrow for 2002-2013, at Tiksi for 2009-2013, and at Zeppelin for 2002-2013. At Villum station, EC data were available for 2008-2011. The EC and eBC data were directly compared with modelled BC concentrations for the same locations and periods. Tiksi data were not filtered for a clean air sector and may have been affected by local pollution events. Barrow and Alert data were routinely subject to data clean- ing, which removed the influence from local sources. Zeppelin generally was not strongly influenced by local emissions; however, summer values were enhanced by some $11 \%$ due to local cruise ship emissions (Eckhardt et al., 2013).

\section{Results}

\subsection{Emission, transport, and deposition of $\mathrm{BC}$}

Northern Eurasia encompasses diverse ecosystems including forest, shrubland, cropland, grassland, and savanna (Friedl et al., 2002). The total burned areas (excluding agricultural fires) during the period of 2002-2013 were estimated to be $250000 \mathrm{~km}^{2} \mathrm{yr}^{-1}(n=12)$ (Hao et al., 2016), which consisted of $61 \%$ of grassland and $27 \%$ of forest. Grassland fires occurred predominantly over central and western Asia, and forest fires over Siberia in Russia. The years 2003, 2006, and 2008 showed respectively 96,40 , and $30 \%$ more burn scars than the annual mean from 2002 to 2013 (Fig. S1 in the Supplement). The unusual high fire activity in 2003, 2006, and 2008 was a result of extensive grassland fires over central and western Asia, and forest and grassland fires over Russia.

Table 2 presents the yearly mean atmospheric emissions of $\mathrm{BC}$ from anthropogenic and $\mathrm{BB}$ sources for the period 2002-2013 from FEI-NE+MACCity and MACCity. Annual global $\mathrm{BC}$ emissions varied in a range from $8.02 \mathrm{Tg} \mathrm{yr}^{-1}$ in 2007 to $9.48 \mathrm{Tg} \mathrm{yr}^{-1}$ in 2003 with an average: $8.42 \pm 0.43 \mathrm{Tg} \mathrm{yr}^{-1}$ over the period 2002 to 2013 according to FEI-NE+MACCity. These values compared well with other published results. For instance, Wang et 


\begin{tabular}{|c|c|c|}
\hline 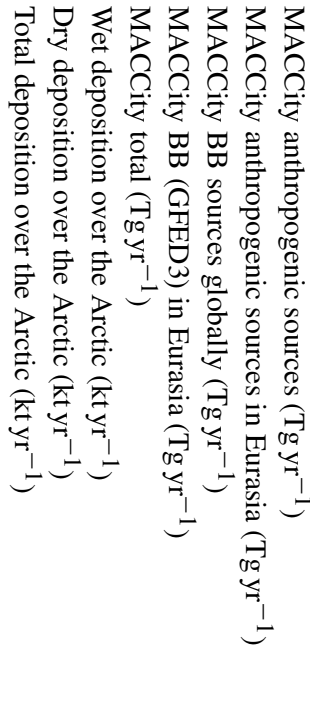 & 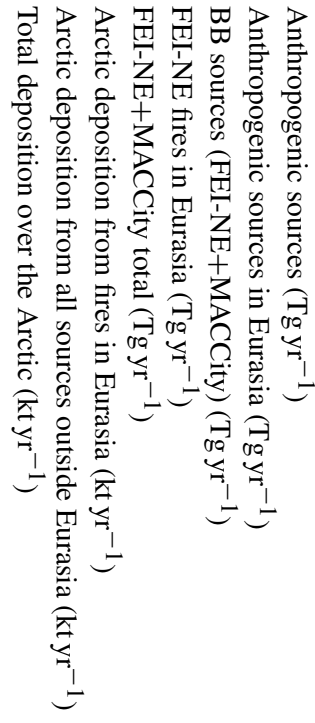 & \\
\hline$g$ u & 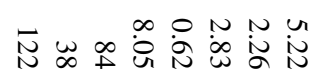 & 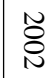 \\
\hline 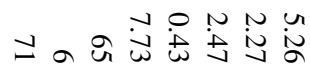 & 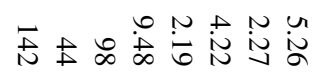 & $\stackrel{N}{\mathscr{O}}$ \\
\hline 光 a y & 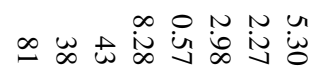 & 胥 \\
\hline 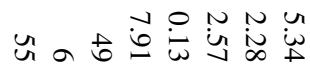 & 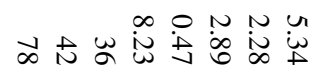 & 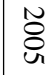 \\
\hline 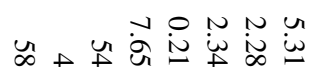 & 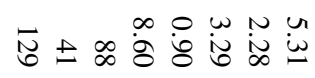 & 路 \\
\hline 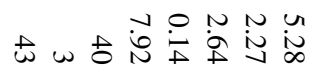 & 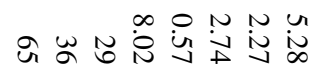 & $\stackrel{0}{8}$ \\
\hline 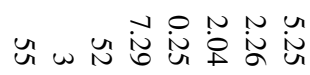 & 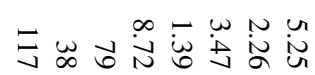 & $\mathbb{D}_{\infty}^{0}$ \\
\hline y u u & 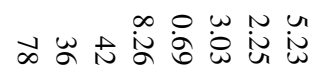 & 胥 \\
\hline 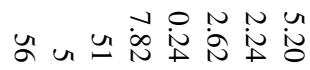 & 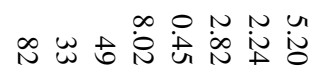 & 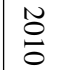 \\
\hline un u u & 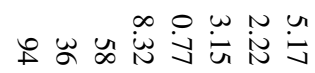 & $\stackrel{N}{O}$ \\
\hline un un & 崔 & $\stackrel{\text { O }}{\mathrm{N}}$ \\
\hline 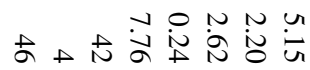 & 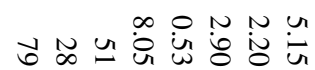 & $\underset{\omega}{\stackrel{0}{\sigma}}$ \\
\hline 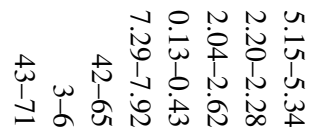 & 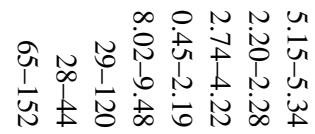 & $\underset{\mathscr{0}}{\widetilde{\sigma}}$ \\
\hline
\end{tabular}

al. (2014) reported that, according to the PKU-BC-2007 (Peking University BC Inventory for 2007) inventory of global BC emissions (both anthropogenic and biomass burning sources), a total amount of $8.9 \mathrm{Tg} \mathrm{yr}^{-1}$ was emitted in 2007. The ECLIPSE inventory estimated for 2010 by Eckhardt et al. (2015) was $8.32 \mathrm{Tg} \mathrm{yr}^{-1}$, only slightly higher than our estimations of $8.02 \mathrm{Tg} \mathrm{yr}^{-1}$. In contrast, the ACCMIP $\mathrm{BC}$ emissions for 2005 (Lamarque et al., 2010) was $15 \%$ lower (e.g. $\sim 7.82 \mathrm{Tg} \mathrm{yr}^{-1}$ compared to $8.13 \mathrm{Tg} \mathrm{yr}^{-1}$ ). BC emissions from vegetation fires in northern Eurasia ranged between 0.45 and $2.19 \mathrm{Tg} \mathrm{yr}^{-1}$ for the period 2002-2013, representing $20 \%$ to $49 \%$ of the total BC emissions over this region. In comparison, the emissions over the same region based on the MACCity inventory ranged between 0.13 and $0.43 \mathrm{Tg} \mathrm{yr}^{-1}$ and accounted for 5 to $16 \%$ of total $\mathrm{BC}$ emissions. The BC emissions in the Northern Hemisphere (FEI-NE+MACCity) were classified as $70 \%$ from anthropogenic sources and $30 \%$ from BB. Northern Eurasian vegetation fires accounted for $56 \%$ of the BB BC emissions in the Northern Hemisphere.

$\mathrm{BC}$ emissions from FEI-NE were relatively constant in time except for four $(2003,2006,2008,2012)$ intense years (Fig. S2). Similarly, the GFED3 of MACCity showed relatively high emissions in some of these years (2003 and 2006), but the relative emission increase was significantly lower for these years (Table 2). The fire episodes that occurred in northern Eurasia during these extreme fire years were particularly intense. In 2003, fire events in the Transbaikal region (Russian provinces Chita and Buryatia) caused severe smoke pollution in the Far East of the Russian Federation (IFFN, 2004), while in spring 2006, smoke from peat and forest fires in the western Russian Federation was noticed as far as the United Kingdom (Hao et al., 2009) and in the Arctic (Stohl et al., 2007). In summer 2006, smoke from vegetation fires in the Russian Federation persisted for weeks over Finland (GFMC, 2006).

Figure 1 depicts deposition anomalies of $\mathrm{BC}$ for the period 2002-2013. A remarkable feature was that the highest anomalies were observed in the northernmost part of Asia and in the Arctic in 2003, 2006, 2008, and 2012. Taking into account emissions fluxes from these years (Fig. S2), one can note that the largest amounts of BC were deposited over Arctic regions as a result of large fire events in Siberia, western Russia, and Kazakhstan. The annual amount of BC deposited over the Arctic from all possible global sources (including $\mathrm{BB})$ during the 12-year period ranged from 65 to $152 \mathrm{kt} \mathrm{yr}^{-1}$ (average: $102 \pm 29 \mathrm{kt} \mathrm{yr}^{-1}$ ) representing about $0.9-18 \%$ of total global emissions. The total annual deposition of $\mathrm{BC}$ to the Arctic from vegetation fires in northern Eurasia (FEI-NE) during the same period ranged between 29 and $120 \mathrm{kt} \mathrm{yr}^{-1}$ (average: $65 \pm 28 \mathrm{kt} \mathrm{yr}^{-1}$ ) or about $0.3-14 \%$ of total global $\mathrm{BB}$ emissions (Table 2). Hence, more than half of the total $\mathrm{BC}$ that deposited over the Arctic originated from BB in northern Eurasia, which underlines the importance of the 


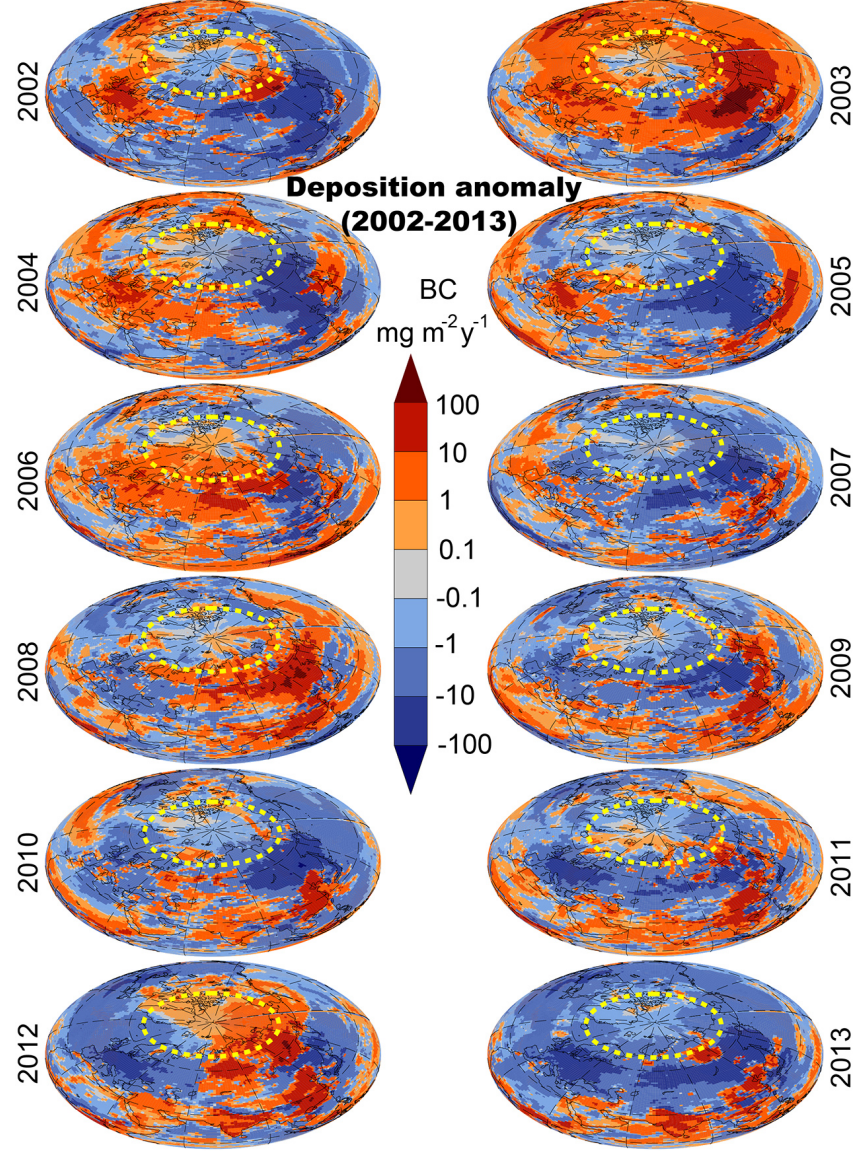

Figure 1. Deposition anomalies of $\mathrm{BC}\left(\mathrm{mg} \mathrm{m}^{-2} \mathrm{yr}^{-1}\right)$ in the Northern Hemisphere for the period 2002-2013 from our combined simulation (FEI-NE+MACCity) in northern Eurasia. The dashed yellow line represents the border of the Arctic $\left(\sim 67^{\circ} \mathrm{N}\right)$. Note that the most intense years were estimated to be 2003, 2006, 2008, and 2012.

northern Eurasian vegetation fires on the Arctic BC budget compared with contributions of other sources.

Figure 2 illustrates BC deposition from FEI-NE detected vegetation fires only, excluding anthropogenic sources, while Fig. S3 shows the deposition from all sources (FEINE+MACCity). For the most intense fire years, 2003, 2006, 2008, and 2012, annual amounts of 142, 129, 117, and $152 \mathrm{kt} \mathrm{yr}^{-1}$ of BC were respectively deposited over the Arctic from northern Eurasian vegetation fires (Table 2). They amount to 3.2 to 4.1 times the $37 \pm 5 \mathrm{kt} \mathrm{yr}^{-1}$ average (2002 to 2013) deposition flux for anthropogenic sources over northern Eurasia. Finally, when using MACCity emissions, both from anthropogenic and $\mathrm{BB}$ sources, the estimated average deposition of $\mathrm{BC}$ over the Arctic was $56 \pm 8 \mathrm{kt} \mathrm{yr}^{-1}$ for the period 2002-2013. Consequently, Arctic deposition was lower by $45 \%$ compared to FEI-NE, when BB emissions of $\mathrm{BC}$ from GFED (MACCity) were used.
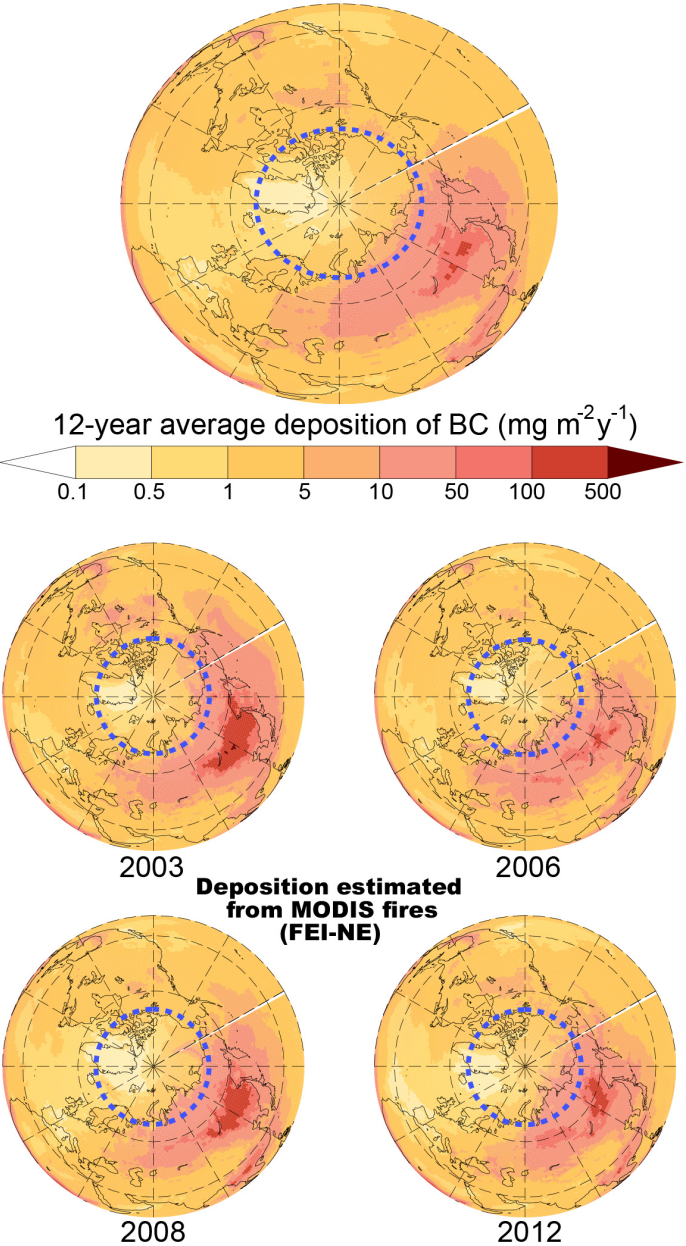

Figure 2. Arctic deposition of $\mathrm{BC}\left(\mathrm{mg} \mathrm{m}^{-2} \mathrm{yr}^{-1}\right)$ from BB emission according to the FEI-NE inventory. The upper panel depicts the 12-year average deposition, while the lower four panels show the most intense fire years $(2003,2006,2008$, and 2012). The dashed blue line represents the border of the Arctic $\left(\sim 67^{\circ} \mathrm{N}\right)$.

\subsection{Aerosol lifetime and seasonality of $\mathrm{BC}$}

Figure 3 depicts the global mean aerosol lifetimes for anthropogenic and BB BC from the combined FEI-NE+MACCity simulation. The results are given in box and whisker plots of daily lifetimes for the 12-year period. Mean aerosol lifetimes for anthropogenic BC were stable for all the studied years with an annual average value of $5.6 \pm 0.2 \mathrm{~d}$. Mean aerosol lifetimes of BC from FEI-NE+MACCity simulation exceeded these lifetimes by 1.2 days $(6.8 \pm 1.0 \mathrm{~d})$. The pronounced variability of the mean lifetime of BB BC was attributed to the variability in regions and injection height. According to the injection scheme used (Sofiev et al., 2013), continuous injection close to the PBL (around $65 \%$ of the mass of $\mathrm{BC}$ is emitted up to $0.8 \mathrm{~km}, 90 \%$ up to $1.1 \mathrm{~km}$ ) results in accumulation of $\mathrm{BC}$ in the troposphere, where longer lifetime occurs compared to the PBL. This was likely the 


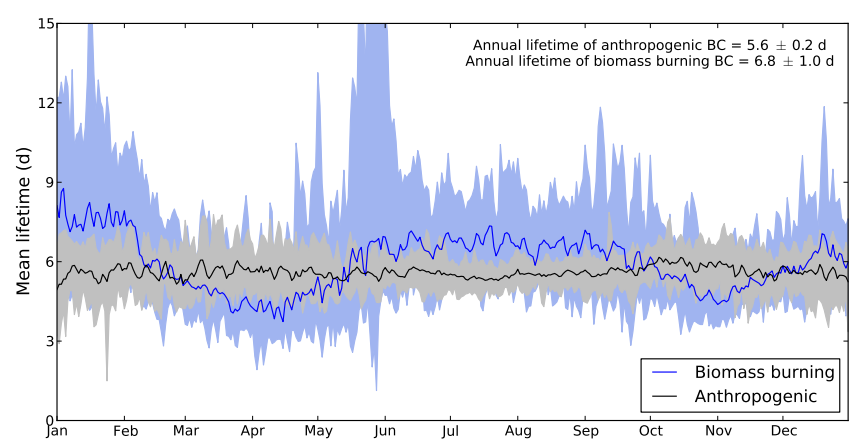

Figure 3. Annual mean global lifetime ( \pm standard deviation) of the global anthropogenic and BB BC from our combined FEINE+MACCity simulation. The results show minimum, average, and maximum daily lifetimes of BC (both for anthropogenic and BB) for the period 2002-2013.

main reason for transport of $\mathrm{BC}$ into the Arctic. For any soluble species emitted in the PBL, the lifetime is controlled by the removal, which happens within a few days if it is not transported to the free troposphere. Two weeks after being injected into the atmosphere, most of the tropospheric aerosol was scavenged through wet deposition, whereas aerosols that have been transported into the high troposphere/lower stratosphere persist, given the absence of wet scavenging at these heights. The total aerosol mass and the lifetimes are then dominated by the stratospheric loading (Cassiani et al., 2013).

Mean aerosol lifetimes from global models are typically in the range of 3-7 days (Benkovitz et al., 2004; Textor et al., 2006), very similar to our estimations for BC, but more variable in this study due to the higher injection heights of $\mathrm{BC}$ in smoke plumes. As stated, in the present case of wildfires in northern Eurasia, the lifetimes and the behaviour of BC was strongly affected by the fact that it was directly emitted aloft. Although 80-90\% of BC was emitted inside the PBL, nearly $65 \%$ of the BC was emitted near the PBL height, while $10 \%$ was injected above (according to Sofiev et al., 2013).

In this study, we analysed monthly values of both the Arctic $\mathrm{BC}$ burden and the mass deposited in the Arctic for all BC sources (FEI-NE+MACCity) and for BC produced from BB sources only over northern Eurasia (FEI-NE). A strong seasonal variation can be seen in both Arctic burden and deposition (Fig. 4a, b, c, and d). Relatively high BC burden from the combined emissions of the FEI-NE+MACCity run occurred in winter (December-January, Fig. 4b), while two peaks were found in late spring and in summer for intense fire years. The latest were clearly caused by spring and summer fire events over northern Eurasia (Fig. 4). The higher winter values corresponded to the meridional transport of $\mathrm{BC}$, mostly emitted from anthropogenic sources (Fig. 4a). These large increases in the burden were not proportional among the different aerosol modes (hydrophilic and hydrophobic) and affected mostly hydrophilic BC aerosol from vegetation fires. This indicated that wet scavenging was less efficient than the rest of the year along the transport path between mid- and high-latitudes. A spring maximum was also simulated for BC deposition over the Arctic. It was caused by a combination of anthropogenic BC in the Northern Hemisphere and fires in northern Eurasia (Fig. 4a and c), the majority of which occurred between March and May. The annually deposited mass of BC over the Arctic exceeded the annual average for the period 2002-2013 by $52 \%$ in 2003 and $86 \%$ in 2012 .

There were three noteworthy findings. First, the year 2012 appeared to be a year when BC transport to the Arctic was particularly efficient. Although the year itself (2012) was not an extreme fire year (Fig. S1) in terms of burn scars, it appeared that the prevailing winds and the lack of scavenging in mid-latitudes during June and July, when fires were most intense, favoured transport and subsequent deposition to highlatitudes ( $120 \mathrm{kt}$ from vegetation fires only and $152 \mathrm{kt}$ from all possible sources). Second, we simulated a higher relative contribution of wet to total deposition in the Arctic $(90 \%)$ than at mid-latitudes (69\%). Third, the annual mean lifetime of anthropogenic BC particles from BB was longer $(6.8 \mathrm{~d})$ than for BC from combustion $(5.6 \mathrm{~d})$. These values are within the range of other published results (e.g. 5.8 days from Park et al., 2005 and 7.3 days from Koch and Hansen, 2005).

\subsection{Geographic distribution of sources contributing to the Arctic BC}

In this section, we compare the contributions from different source regions and from different emission types to the deposition of BC in the Arctic region. Several simulations with $\mathrm{BC}$ tracers tagged by source region were carried out to isolate the different contributions. We selected the following regions (Fig. 5a): Europe, Asia, Siberia, Kazakhstan, and Mongolia, as well as from the latitude bands 35 to $40^{\circ} \mathrm{N}, 40$ to $50^{\circ} \mathrm{N}$, 50 to $60^{\circ} \mathrm{N}$, above $60^{\circ} \mathrm{N}\left(60-90^{\circ} \mathrm{N}\right)$, and also the entirety of northern Eurasia. We discuss the results of these separate simulations and compare them to our FEI-NE+MACCity run (Fig. 5). Each simulation covered the whole period from 2002 to 2013.

Quinn et al. (2007) were the first to report that for BC over the Arctic, anthropogenic sources dominated during winter and early spring Arctic haze conditions. We estimated that anthropogenic emissions accounted for $70 \%$ of the Arctic $\mathrm{BC}$ burden from all sources in the Northern Hemisphere during winter and fall and for $40 \%$ during spring and summer when vegetation fires are most frequent.

Vegetation fires from northern Eurasia contributed $68 \%$ of the annual $\mathrm{BC}$ deposition over the Arctic coming from that same region (Fig. 5d), whereas anthropogenic emissions constituted a lesser share (32\%). Northern Eurasian vegetation fires were the most numerous over the Northern Hemisphere; they contributed $81 \%$ of the Arctic deposition of BC from 


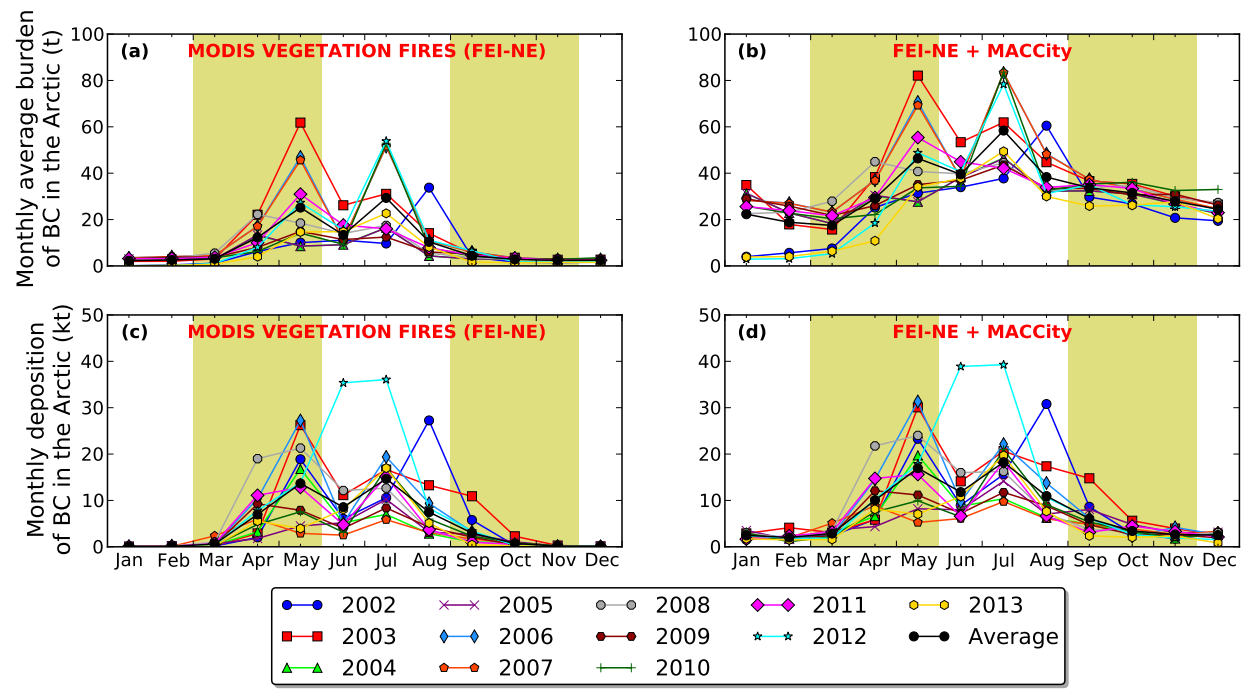

Figure 4. Monthly atmospheric burden of BC (t) in the Arctic with each year between 2002 and 2013 represented by a different coloured line: (a) from vegetation fires (FEI-NE) only and (b) from all BC emissions (FEI-NE+MACCity). Panels (c) and (d) show the same, but for the Arctic deposition of $\mathrm{BC}(\mathrm{kt})$.

Northern Hemispheric fires (Fig. 5d), while the rest came from other sources (e.g. BB in North America).

Of the northern Eurasian BB BC deposition in the Arctic, $95 \%$ was from Asia, while only $5 \%$ came from Europe. On a more regional basis, Siberia contributed $46 \%$ of the northern Eurasian BB BC deposited in the Arctic, whereas Kazakhstan contributed $6 \%$, and Mongolia only $1 \%$. The rest was shared between fire events in Europe $(5 \%)$ and elsewhere in Asia $(42 \%)$ from areas that were not masked.

The relative contributions of fires at different latitudes to the Arctic BB BC deposition were distributed as follows: fires from the 35 to $40^{\circ} \mathrm{N}$ latitudinal band over northern Eurasia contributed only $7 \%$, from 40 to $50^{\circ} \mathrm{N}$ the contribution was $21 \%, 40 \%$ came from fires at $50-60^{\circ} \mathrm{N}$, and $32 \%$ from fires above $60^{\circ} \mathrm{N}$ (Fig. 5c).

Moreover, we examined the vertical distribution of $\mathrm{BC}$ over the Arctic for the different source regions (Fig. 6). When emitted from Europe, BC over the Arctic was found mostly below $5 \mathrm{~km}$ (either in the PBL or the low free troposphere), while $\mathrm{BC}$ emitted from Asia was found in higher layers that extended up to the mid- to high- free troposphere (Fig. 6). Similar vertical distribution for aerosols have been reported by Stohl et al. (2002), who estimated that aerosol originating from Asia was mixed throughout the entire troposphere within a few days.

These findings can be discussed in light of the ones reported by other authors. For instance, our results agree well with those of Hirdman et al. (2010a), who reported that the northern Eurasian region (Europe and Russia) was the main contributor to the Arctic surface concentrations of $\mathrm{BC}$ and sulfate. The present study shows the importance of all the regions north of $50^{\circ} \mathrm{N}$. Stohl (2006) reported that Asia con- tributed 10 times less than Europe to the Arctic BC surface concentrations, which was not supported by our findings for total BC. Our results agreed with the conclusions of Koch and Hansen (2005), who reported that Europe contributed $10 \%$ to the Arctic deposition of BC (anthropogenic and BB). In any case, all surface measurements of $\mathrm{BC}$ over the Arctic indicated that the main contributors to the Arctic $\mathrm{BC}$ during the summer were high-latitude sources (Hirdman et al., 2010a; Sharma et al., 2013).

\section{Discussion}

\subsection{Observed and simulated $\mathrm{BC}$ concentrations at Arctic surface stations}

There are contradictory results in the literature about where geographically the Arctic BC pollution originates. For example, Koch and Hansen (2005) estimated that south-east Asia, Europe, and Russia each contributed about $20-25 \%$ of the Arctic pollution during the period January to March, whereas Stohl (2006) reported that Europe was the main contributor for the Arctic BC concentration at the surface. In addition, Huang et al. (2010) stated that Russia contributed $67 \%$ to the surface Arctic pollution, whereas Europe and North America were 18 and $15 \%$ respectively (16-year observations from Alert). Northern Eurasia appeared to be the main contributor in terms of Arctic BC during most seasons (Hirdman et al., 2010a). More recently, Stohl et al. (2007) and Warneke et al. (2009) reported that boreal and agricultural fires in eastern Europe and in Siberia might be strong contributors to Arctic BC, especially in the spring. Furthermore, Stohl et al. (2013) 


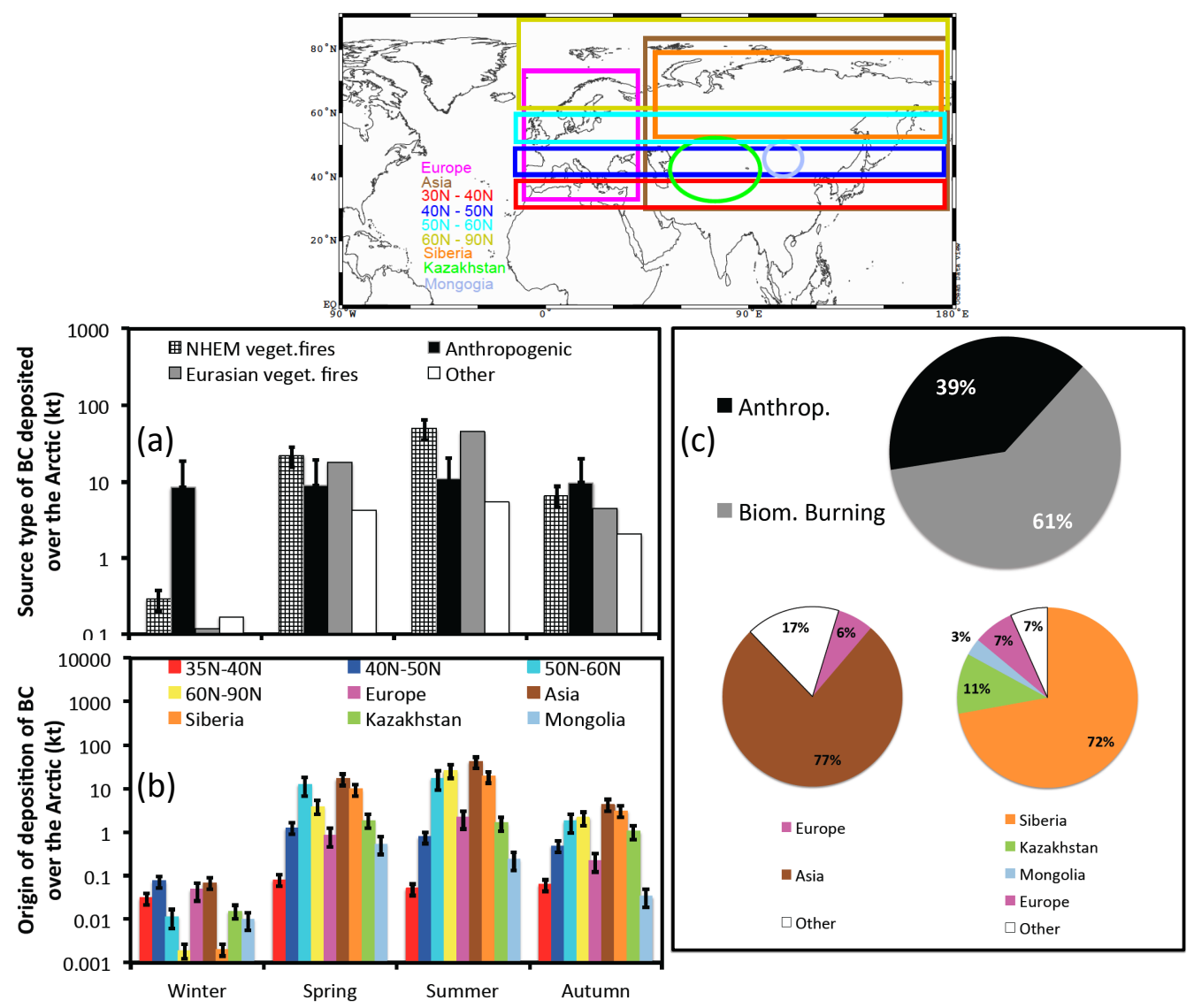

Figure 5. (a) The nine geographic regions of BC emission in northern Eurasia defined for this study. (b) Seasonal values of BC emitted from all fires in the Northern Hemisphere (NHEM), anthropogenic sources (black), and northern Eurasian vegetation fires (grey) deposited in the Arctic for the period of 2002-2013. (c) Contribution of several geographic regions to the Arctic BC deposition. Colours are used according to the ones used in panel (a). Red stands for regions within $35-40^{\circ} \mathrm{N}$, dark blue for $40-50^{\circ} \mathrm{N}$, turquoise for $50-60^{\circ} \mathrm{N}$, yellow for regions located above $60^{\circ} \mathrm{N}\left(60-90^{\circ} \mathrm{N}\right)$, magenta for Europe, brown for Asia, orange denotes Siberia, green for Kazakhstan, and light blue for Mongolia. (d) Pie-charts showing the origin of BC deposition in the Arctic from anthropogenic sources (MACCity), vegetation fires in northern Eurasia (FEI-NE) and BB outside northern Eurasia.

highlighted gas-flaring emissions in high latitudes as a major contributor to the Arctic BC.

Figure 8 compares the simulated surface BC concentrations from this study with in situ $\mathrm{EBC}$ and $\mathrm{EC}$ measurements from monitoring stations at Alert (Canada), Barrow (Alaska, USA), Villum (Greenland, Denmark), Zeppelin (Ny-Ålesund, Svalbard, Norway), and Tiksi (Russian Federation). The observations, when available, were represented for the entire period of our simulations (2002-2013). At Zeppelin and Barrow stations, the measurements were available between 2002 and 2013, at Alert from 2005 to 2013, at Villum from 2008 to 2011, and at Tiksi station from 2009 to 2013. Figure 7 compares the simulated vs. observed daily surface concentrations by a box and whisker plot at the five Arctic stations (Alert, Barrow, Villum, Tiksi, Zeppelin) for the period 2002 to 2013.

At Alert, there was a systematic underestimation in winter and early spring and an overestimation in late spring and summer, when the station did not record any enhanced eBC concentrations that would be attributed to vegetation fires in northern Eurasia (Figs. 7 and S2). At Barrow, the model not only accurately estimated surface concentrations during winter, when the Arctic haze is important, but also in spring and summer, when vegetation fires persisted (Figs. 7 and S2). At Villum, the measured seasonality was reproduced quite well by the model and individual episodes of elevated BC surface concentrations in spring and summer were also captured and attributed to vegetation fires. At the Tiksi station, the comparison showed a notable deviation from the measurements. Although some peaks in spring and summer were captured, the model completely missed the high concentrations of eBC in winter and early spring. Finally, at Zeppelin, it appeared that the anthropogenic BC contribution was slightly underestimated (spring), while vegetation fires in northern Eurasia elevated modelled surface concentration of BC. 


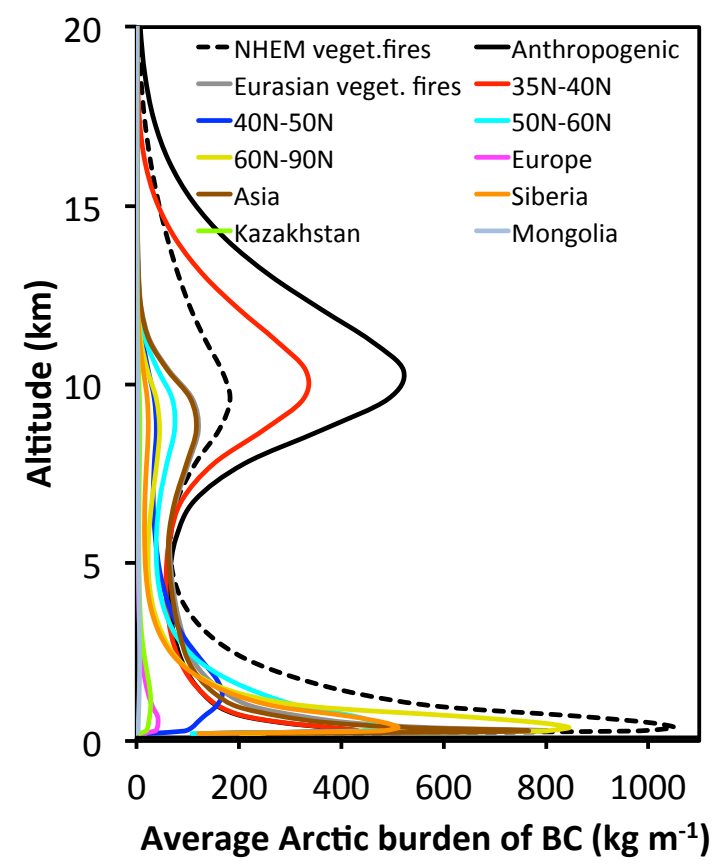

Figure 6. Annual average (2002-2013) vertical profiles of atmospheric burden of $\mathrm{BC}\left(\mathrm{kg} \mathrm{m}^{-1}\right)$ in the Arctic originating from different regions.

Looking at other inventories and results from the Lagrangian particle dispersion model FLEXPART, we are convinced that local anthropogenic sources play an important role in the apparition of these peaks (Eckhardt et al., 2015). It was already noted that our model underestimated surface concentrations at Alert and Villum stations during the Arctic haze period. This is likely the consequence of an underestimation of Arctic transport in the model or a misleading emission inventory used for anthropogenic sources (MACCity). To verify it, we estimated surface concentrations of $\mathrm{BC}$ in the same longitude as the five Arctic stations, but five and ten degrees south in latitude (Fig. S4). In all stations except Tiksi, surface concentrations increased to the south confirming that the underestimation by our model over the Arctic could be attributed to a too-weak transport simulated towards the Arctic.

It has been reported that most models underestimated BC in the Arctic during winter and early spring (Eckhardt et al., 2015), likely due to an improper representation of the scavenging processes (lack of below-cloud scavenging for solid phase water), the different emission profiles used for BC, and underestimated emission inventories used as input to the models (e.g. Koch and Hansen, 2005; Liu et al., 2011; Jiao et al., 2014). Using the FEI-NE+MACCity inventory, BC concentrations over the Arctic are reasonable compared to observations, with a tendency to underestimate winter concentrations but capturing some summer peaks. Figure 7 also shows that using MACCity emissions globally, spring and

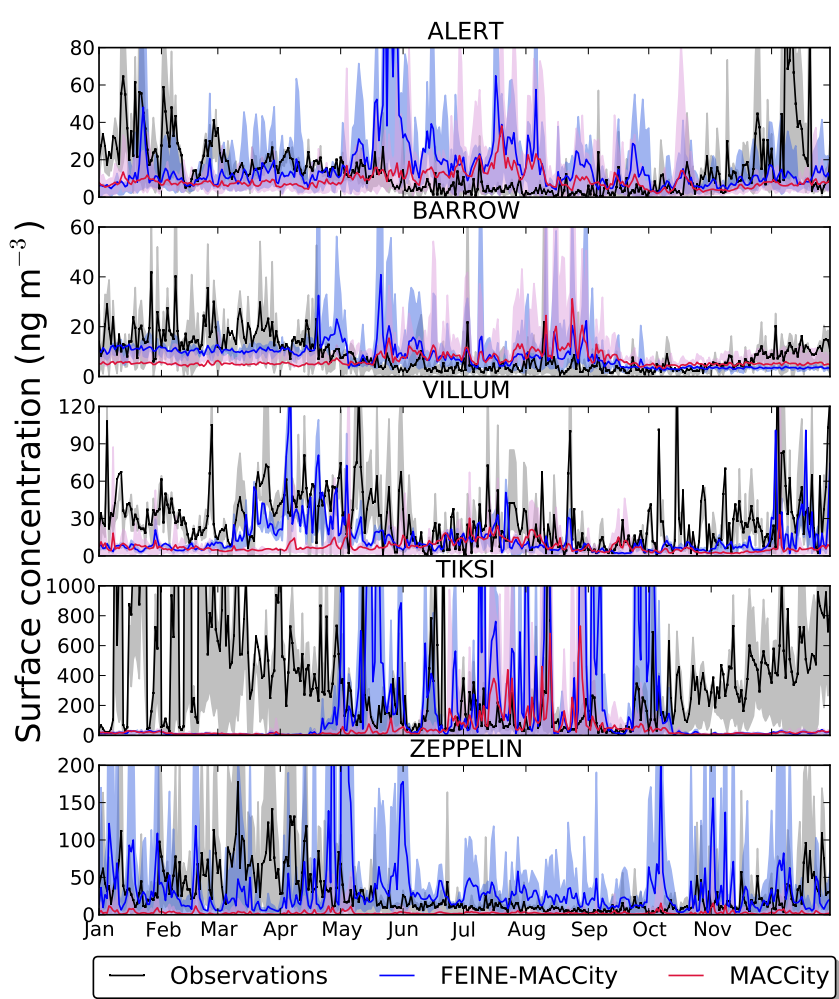

Figure 7. Modelled vs. measured surface concentrations of $\mathrm{BC}$ $\left(\mathrm{ng} \mathrm{m}^{-3}\right)$ for the FEI-NE+MACCity and MACCity simulations in the Arctic stations Alert, Barrow, Villum, Tiksi, and Zeppelin. Due to the high variability of the surface concentrations, the results are presented as minimum, average, maximum modelled (FEINE+MACCity and MACCity) and measured surface daily concentrations of BC for the period 2002-2013.

summer concentrations are rather underestimated (e.g. in Villum, Tiksi, and Zeppelin). In both cases, misleading anthropogenic emissions appear to be the main problem during winter. The largest deviations occur at the station Tiksi, Russia. The station is located only a few kilometres away from Tiksi town and local pollution is likely to affect the measurements, as the town has both a small airport and a harbour. Despite these drawbacks at Tiksi station, the data from the station has been used to estimate the sources in northern Eurasia (Cheng, 2014). Eckhardt et al. (2015) compared both surface- and aircraft measurements of sulfate and BC in the Arctic to model output from eleven different models. They found that the models generally underestimated the surface concentrations of $\mathrm{BC}$ and sulfate in winter and spring, whereas concentrations in summer were overestimated. They also found a strong correlation between surface measured sulfate and $\mathrm{BC}$ concentrations in winter and spring (anthropogenic impact), which indicated that the sources contributing to sulfate and $\mathrm{BC}$ were similar throughout the Arctic and that the aerosols were internally mixed and undergo similar removal. Neither Eckhardt et al. (2015) nor Samset et 


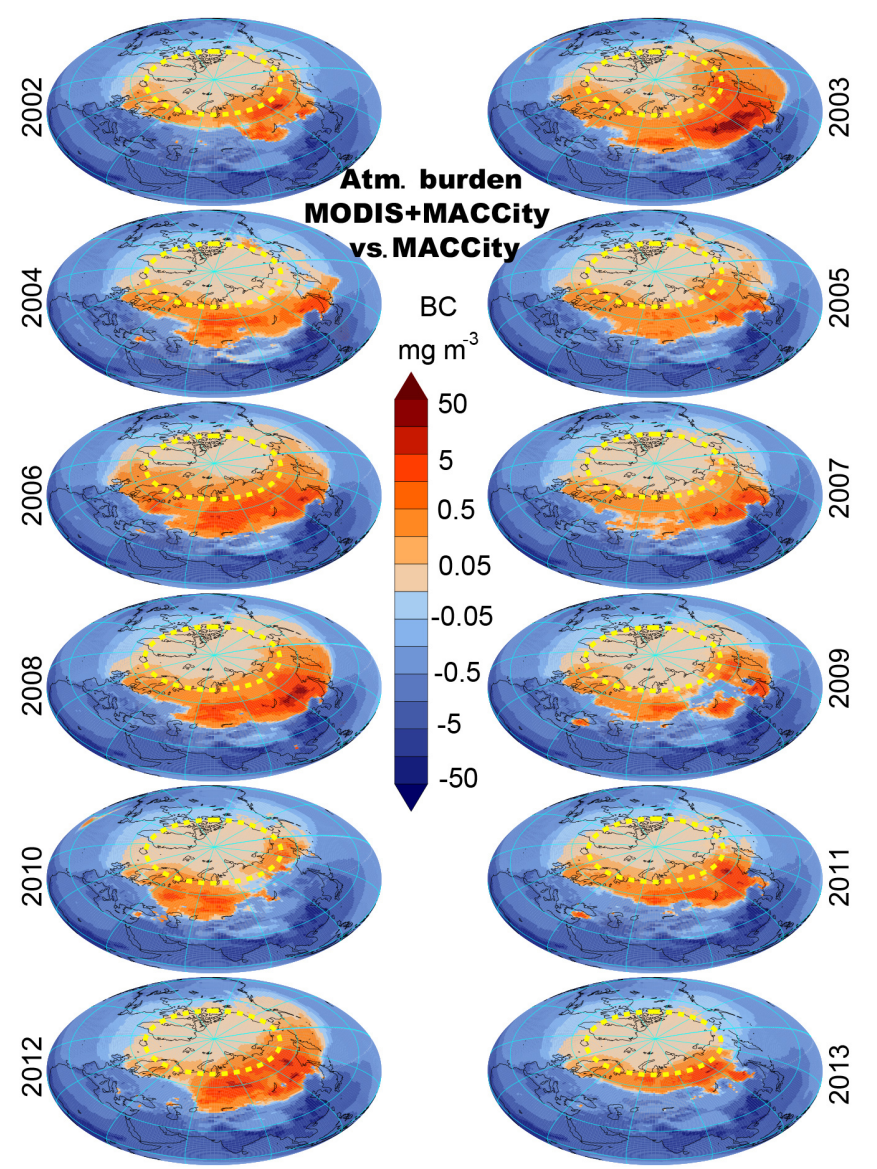

Figure 8. Difference in $\mathrm{BC}$ atmospheric burden $\left(\mathrm{mg} \mathrm{m}^{-3}\right)$ between our simulation that combines emission inventories (FEINE+MACCity) and MACCity. The dashed yellow line represents the limit of the Arctic $\left(\sim 67^{\circ} \mathrm{N}\right)$. The BC burden was estimated by summing all the vertical layers and averaging with time (365 days) for each of the years between 2002 and 2013.

al. (2014) could isolate the reason to explain why some models performed better than the others.

In the present model configuration, we included the emission inventory from FEI-NE and MACCity's anthropogenic $\mathrm{BC}$ inside northern Eurasia and MACCity (BB and anthropogenic) outside northern Eurasia (FEI-NE+MACCity) respectively to evaluate if it produced reliable results with respect to observations. The question that stemmed from this comparison was whether or not existing datasets included all possible sources of $\mathrm{BC}$ emission. This was examined by comparing the FEI-NE+MACCity inventory with MACCity, which included lower BC global emissions. Figure 8 depicts the difference of the average atmospheric burden of BC between FEI-NE+MACCity and MACCity runs, while Figs. S5 and S6 show the same comparison for emissions and Arctic deposition of BC. It is apparent that the difference in average atmospheric burden between the FEI-NE+MACCity and MACCity simulations (Fig. 8) is positive over northern
Eurasia and over the Arctic, showing that vegetation fires in northern Eurasia have a direct impact on the Arctic budget, especially during the most intense fire years $(2003,2006$, 2008, and 2012). The aforementioned impact extends up to North America and may affect the BC concentrations there as well. Subsequently, the deviation of the deposition of BC from northern Eurasian vegetation fires relative to FEI-NE is shown to be large over the Arctic (Fig. S6).

We also analysed the influence of anthropogenic emissions, as well as BB emissions from the regions (defined in Table 1) to the average surface concentration of the Arctic stations (Fig. 9). As expected, the predominant contributor to the surface concentrations of the Arctic stations was Northern Hemisphere anthropogenic emissions (29-55\%) (e.g. Shaw et al., 2010). The explanation is twofold. On one hand, transport of $\mathrm{BC}$ from the southern latitudes to the Arctic takes place as the air masses follow the trajectories of potential difference in temperature (a dome effect); they are lifted up, leaving the surface, especially from North America and Asia (China). On the other hand, transport from Russia/Siberia during the winter and spring is closer to the surface due to large anthropogenic emissions that are also effectively transferred from Europe. In addition, transport of BC from Russia/Siberia is less efficient during summer due to pressure systems that block the $\mathrm{BC}$ transport. Fires from northern Eurasia contributed less BC to Barrow, Zeppelin, and Villum, while this pattern changed for Alert and Tiksi stations (Fig. 9). This shows that emissions from northern Eurasia may extend up to the American Arctic (Barrie, 1986). The region marked as "other" in Fig. 9 stands for all BB emissions occurring over the Northern Hemisphere, excluding northern Eurasia, and shows that $4-42 \%$ of the surface concentrations may be due to fires in North America and other BB sources. In all cases, fires in regions north of $50^{\circ} \mathrm{N}$ contributed the most, especially to Tiksi station. Fires in the Asian part of northern Eurasia contributed to the surface concentrations of the stations by 13 to $57 \%$, with the maximum at Tiksi station. This was expected since this station is in the middle of the northern Eurasian Arctic region and receives a lot of BC emitted from BB in Siberia. The respective portion for fires occurring in Europe was estimated to be only $1-2 \%$. Similarly, BC emitted from Siberia contributed $9-43 \%$ to the simulated surface concentrations at the stations (with a maximum in Tiksi station). We estimated that the total of all vegetation fires in northern Eurasia contributed around $56 \mathrm{ng} \mathrm{m}^{-3}$, on average, to the Alert station (during spring and summer months), which is close to the $89 \mathrm{ng} \mathrm{m}^{-3}$ that Huang et al. (2010) estimated for the USSR and European Union, although with different geographic definitions than those assumed here, and also including anthropogenic emissions. Gong et al. (2010) and Shindell et al. (2008) estimated that the northern Eurasian contribution to Alert varied between 80-90\%, while our runs suggested a lower BB contribution (29\%). Nevertheless, considering our comparison of modelling results with surface observations for $\mathrm{BC}$ 


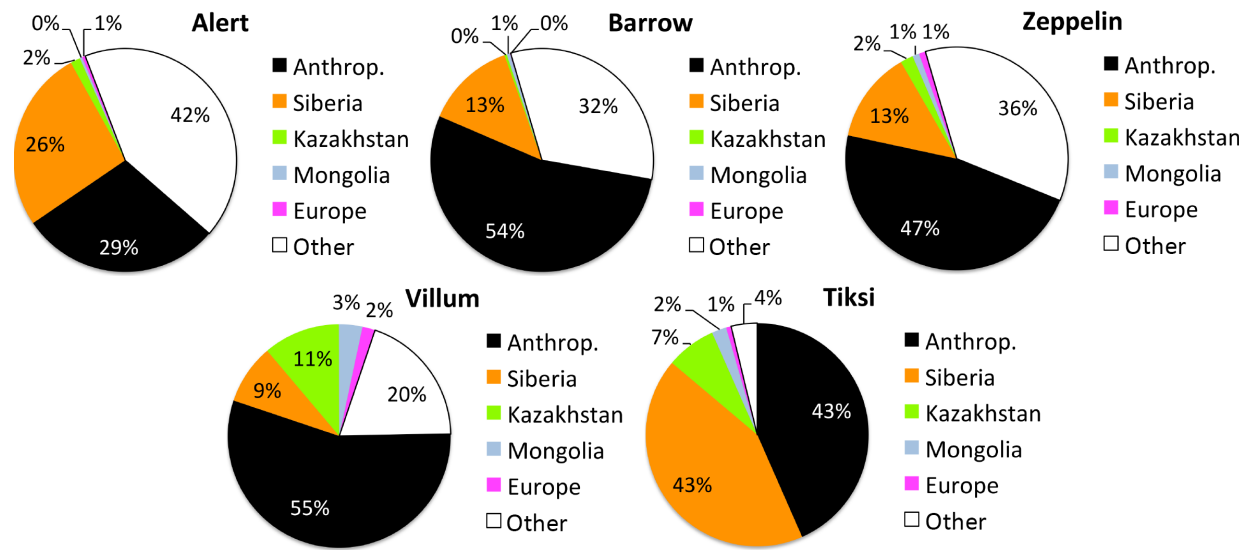

Figure 9. Multi-year average (2002-2013) contribution of global anthropogenic and BB BC from the respective geographic regions to surface concentrations at the Arctic stations (Alert, Barrow, Zeppelin, Villum, and Tiksi). Region "other" stands for other locations where BB sources were not accounted for.

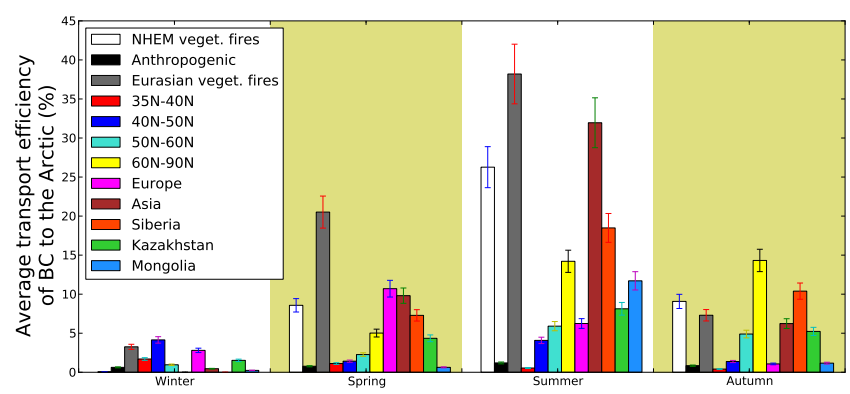

Figure 10. Relative transport efficiency of $\mathrm{BC}$ from vegetation fires from different geographic regions across the Arctic. The same colours were used as in Fig. 5.

from the five Arctic stations, it should be noted that the calculated contribution constituted an upper bound, especially when considering Asian and Siberian regions.

\subsection{Transport efficiency of $\mathrm{BC}$ to the Arctic}

In this section, we examine the relative roles of different regions to emitting $\mathrm{BC}$ that will ultimately be deposited over the Arctic. To do so, we computed the probability of $\mathrm{BC}$ emitted from different regions to reach the Arctic (based on FEI-NE). We defined the transport efficiency to the Arctic as the ratio between the mass of $\mathrm{BC}$ deposited in the Arctic and the total mass of $\mathrm{BC}$ emitted from a given region. These estimates were obtained by masking the same geographical regions as in Sect. 3.3 (anthropogenic sources in the Northern Hemisphere, vegetation fires in Europe, Asia, between 35 and $40^{\circ} \mathrm{N}, 40$ and $50^{\circ} \mathrm{N}, 50-60^{\circ} \mathrm{N}$ and above $60^{\circ} \mathrm{N}$ ) and simulating fires that occurred inside the masked areas for the period 2012-2013 (Table 1).

Figure 10 depicts the transport efficiency with which BC from vegetation fires reached the Arctic for the different geographic regions. The results clearly show that anthropogenic
$\mathrm{BC}$ from large emitting regions in south-eastern Asia and other Asian regions were not transported efficiently to the Arctic. The main source contributing to Arctic deposition was BB in northern Eurasia with a transport efficiency of $10-32 \%$ during spring and summer and $1-6 \%$ in autumn and winter. Overall, the transport and subsequent deposition of $\mathrm{BC}$ from Asia was more effective than from Europe (12\% of the BB emissions from Asia were deposited in the Arctic, whereas only $5 \%$ of the European BB emissions reach the Arctic), which was attributed to the fact that European $\mathrm{BC}$ tends to remain close to the PBL (Fig. 10), whereas the Asian BC mixes up rapidly into the free troposphere (Stohl et al., 2002). Therefore, European BC was much more affected by removal processes since its transport to the Arctic is much less efficient.

In contrast, Siberian BC was deposited very efficiently to the Arctic in summer and autumn similar to fires above $60^{\circ} \mathrm{N}$ (besides, Siberia covers the Asian part of the $60-90^{\circ} \mathrm{N}$ area). However, it was evident from our results that in our model the most efficient regional transport of $\mathrm{BC}$ to the Arctic occurred in the summer months and was attributed to vegetation fires in Kazakhstan and Mongolia (apart from Siberia, Fig. 10). To summarize these results, the highest transport efficiencies in our model occurred in the spring and summer for all of northern Eurasia. This may be a result of (i) extreme fire events, (ii) the relatively weak removal processes occurring in midand high-latitudes which favour transport without removal of $\mathrm{BC}$, and (iii) the imposed fixed injection profiles used in these simulations.

\section{Conclusions}

The present study focused on the impact of vegetation fires occurring in northern Eurasia on BC deposition in the Arctic. For this reason, a three-dimensional global transport model (LMDz-OR-INCA) was used to simulate fire events 
that took place during 2002-2013. Anthropogenic emissions were adopted from MACCity inventory, while BB emissions within northern Eurasia were from FEI-NE and beyond northern Eurasia from MACCity's GFEDv3 database.

A total of $3.0 \times 10^{6} \mathrm{~km}^{2}$ was burned during the 12-year period in northern Eurasia with the majority being grassland and forest fires. Total global emissions of $\mathrm{BC}$ ranged from 8.02 to $9.48 \mathrm{Tg} \mathrm{yr}^{-1}$ (average: $8.42 \pm 0.43 \mathrm{Tg} \mathrm{yr}^{-1}$ ) with the highest ones recorded for the years 2003, 2006, 2008, and 2012. The annual emissions from vegetation fires in northern Eurasia were estimated to be between 0.45 and $2.19 \mathrm{Tg} \mathrm{yr}^{-1}$ (average: $0.86 \pm 0.51 \mathrm{Tg} \mathrm{yr}^{-1}$ ). Compared to the MACCity emission inventory, our simulations suggested that 10-17\% (average: $8 \%$ ) more BC was emitted by FEI-NE+MACCity, while FEI-NE biomass burning emissions were 3.5 times higher than GFED3.

The annual mean deposition of $\mathrm{BC}$ in the Arctic from vegetation fires in northern Eurasia was found to be $65 \pm 28 \mathrm{kt} \mathrm{yr}^{-1}$ for the 12-year period, which represents 45 $78 \%$ of the BC deposited from all possible sources and origins. The combined run (FEI-NE+MACCity) brought around $55 \%$ (1218 vs. $675 \mathrm{kt}$ in total for the 12-year period) more $\mathrm{BC}$ to deposit over the Arctic environment compared to the conventional MACCity emission inventory.

Arctic burden showed a strong seasonal variation, which peaks during late winter and early spring in the presence of the Arctic haze. The peak in winter depicted the latitudinal transport of BC mainly from anthropogenic sources in Europe, whereas the peak in spring and summer clearly stemmed from the fire episodes in northern Eurasia. The annual mass of $\mathrm{BC}$ deposited over the Arctic increased during the most intense fire years (37\% in 2009 to $181 \%$ in 2012) in comparison to the annual average for the period of 20022013.

Fires occurring in the Northern Hemisphere contributed $68 \%$ to the simulated deposition of $\mathrm{BC}$ in the Arctic, while the rest originated from anthropogenic sources. The majority of the vegetation fires in the Northern Hemisphere were attributed to northern Eurasian vegetation fires $(85 \%)$, of which Asia contributed $81 \%$ and Europe only $4 \%$. These results were consistent with what other researchers have reported, as Asian BC experienced fast elevation to the free troposphere and hence long-range transport.

The present results were compared to surface observations from five stations (Alert, Barrow, Villum, Tiksi, and Zeppelin), showing relatively good results and in most stations capturing the trend in surface $\mathrm{BC}$ concentrations (a notable deviation was observed at Alert). We estimated that vegetation fires in northern Eurasia contributed 14 to $57 \%$ to the surface environment of these stations, mostly affected by fires that took place in Siberia. This showed the importance of fires occurring over northern Eurasia in the Arctic BC budget. However, anthropogenic sources also remain essential, contributing 29 to $54 \%$ to the surface of the Arctic stations.

\section{Data availability}

The data used for this paper is available upon request. The observations used to validate the results of the model were directly retrieved from the website of the World Data Centre for Aerosol (http://ebas.nilu.no) and are publicly available.

\section{The Supplement related to this article is available online at doi:10.5194/acp-16-7587-2016-supplement.}

Acknowledgements. This study was supported by the US Forest Service, Rocky Mountain Research Station. We were granted access to the HPC resources of [CCRT/TGCC/CINES/IDRIS] under the allocation 2012-t2012012201 made by GENCI (Grand Equipement National de Calcul Intensif). We would also like to acknowledge the World Data Centre for Aerosol, in which BC measurements from Arctic stations are hosted (http://ebas.nilu.no). Authors would like to acknowledge Dan Veber for calibration and instrument maintenance, as well as other technicians, students, and staff of CFS Alert for maintaining the site. We would also like to acknowledge the project entitled "Emissions of Short-Lived Climate Forcers near and in the Arctic (SLICFONIA)", which is funded by the NORRUSS research program of the Research Council of Norway (Project ID: 233642).

Edited by: F. Fierli

\section{References}

Ackerman, A. S., Toon, O. B., Stevens, D. E., Heymsfield, A. J., Ramanathan, V., and Welton, E. J.: Reduction of tropical cloudiness by soot, Science, 288, 1042-1047, 2000.

Barrie, L. A.: Arctic air pollution: An overview of current knowledge, Atmos. Environ., 20, 643-663, 1983.

Benkovitz, C. M., Schwartz, S. E., Jensen, M. P., Miller, M. A., Easter, R. C., and Bates, T. S.: Modeling atmospheric sulfur over the Northern Hemisphere during the Aerosol Characterization Experiment 2 experimental period, J. Geophys. Res., 109, D22207, doi:10.1029/2004JD004939, 2004.

Bond, T. C. and Bergstrom, R. W.: Light absorption by carbonaceous particles: an investigative review, Aerosol Sci. Tech., 40, 27-67, doi:10.1080/02786820500421521, 2006.

Bond, T. C., Doherty, S. J., Fahey, D. W., Forster, P. M., Berntsen, T., DeAngelo, B. J., Flanner, M. G., Ghan, S., Kärcher, B., Koch, D., Kinne, S., Kondo, Y., Quinn, P. K., Sarofim, M. C., Schultz, M. G., Schulz, M., Venkataraman, C., Zhang, H., Zhang, S., Bellouin, N., Guttikunda, S. K., Hopke, P. K., Jacobson, M. Z., Kaiser, J. W., Klimont, Z., Lohmann, U., Schwarz, J. P., Shindell, D., Storelvmo, T., Warren, S. G., and Zender C. S.: Bounding the role of black carbon in the climate system: A scientific assessment, J. Geophys. Res. Atmos., 118, 5380-5552, 2013.

Browse, J., Carslaw, K. S., Arnold, S. R., Pringle, K., and Boucher, O.: The scavenging processes controlling the seasonal cycle in Arctic sulphate and black carbon aerosol, Atmos. Chem. Phys., 12, 6775-6798, doi:10.5194/acp-12-6775-2012, 2012. 
Cassiani, M., Stohl, A., and Eckhardt, S.: The dispersion characteristics of air pollution from the world's megacities, Atmos. Chem. Phys., 13, 9975-9996, doi:10.5194/acp-13-9975-2013, 2013.

Cavalli, F., Viana, M., Yttri, K. E., Genberg, J., and Putaud, J.-P.: Toward a standardised thermal-optical protocol for measuring atmospheric organic and elemental carbon: the EUSAAR protocol, Atmos. Meas. Tech., 3, 79-89, doi:10.5194/amt-3-79-2010, 2010.

Cheng, M.-D.: Geolocating Russian sources for Arctic black carbon, Atmos. Environ., 92, 398-410, 2014.

Chung, S. H. and Seinfeld, J. H.: Global distribution and climate forcing of carbonaceous aerosols, J. Geophys. Res., 107, 4407, doi:10.1029/2001JD001397, 2002.

Clarke, A. D. and Noone, K. J.: Soot in the Arctic snowpack: A cause for perturbations in radiative transfer, Atmos. Environ., 19, 2045-2053, 1985.

Croft, B., Pierce, J. R., and Martin, R. V.: Interpreting aerosol lifetimes using the GEOS-Chem model and constraints from radionuclide measurements, Atmos. Chem. Phys., 14, 4313-4325, doi:10.5194/acp-14-4313-2014, 2014

ECMWF: ERA Interim, Daily fields, available at: http://apps. ecmwf.int/datasets/data/interim_full_daily/ (last access: 22 January 2016), 2014.

Eckhardt, S., Hermansen, O., Grythe, H., Fiebig, M., Stebel, K., Cassiani, M., Baecklund, A., and Stohl, A.: The influence of cruise ship emissions on air pollution in Svalbard - a harbinger of a more polluted Arctic?, Atmos. Chem. Phys., 13, 8401-8409, doi:10.5194/acp-13-8401-2013, 2013.

Eckhardt, S., Quennehen, B., Olivié, D. J. L., Berntsen, T. K., Cherian, R., Christensen, J. H., Collins, W., Crepinsek, S., Daskalakis, N., Flanner, M., Herber, A., Heyes, C., Hodnebrog, Ø., Huang, L., Kanakidou, M., Klimont, Z., Langner, J., Law, K. S., Lund, M. T., Mahmood, R., Massling, A., Myriokefalitakis, S., Nielsen, I. E., Nøjgaard, J. K., Quaas, J., Quinn, P. K., Raut, J.-C., Rumbold, S. T., Schulz, M., Sharma, S., Skeie, R. B., Skov, H., Uttal, T., von Salzen, K., and Stohl, A.: Current model capabilities for simulating black carbon and sulfate concentrations in the Arctic atmosphere: a multi-model evaluation using a comprehensive measurement data set, Atmos. Chem. Phys., 15, 9413-9433, doi:10.5194/acp-15-9413-2015, 2015.

Eleftheriadis, K., Vratolis S., and Nyeki S.: Aerosol black carbon in the European Arctic: Measurements at Zeppelin station, NyÅlesund, Svalbard from 1998-2007, Geophys. Res. Lett., 36, L02809, doi:10.1029/2008GL035741, 2009.

Emanuel, K. A.: A scheme for representing cumulus convection in large-scale models, J. Atmos. Sci., 48, 2313-2335, 1991.

Evangeliou, N., Balkanski, Y., Cozic, A., and Møller, A. P.: Simulations of the transport and deposition of ${ }^{137} \mathrm{Cs}$ over Europe after the Chernobyl Nuclear Power Plant accident: influence of varying emission-altitude and model horizontal and vertical resolution, Atmos. Chem. Phys., 13, 7183-7198, doi:10.5194/acp13-7183-2013, 2013.

Flanner, M. G., Zender C. S., Randerson J. T., and Rasch P. J.:Present day climate forcing and response from black carbon in 55 snow, J. Geophys. Res., 112, D11202, doi:10.1029/2006JD008003, 2007.

Flanner, M. G., Zender, C. S., Hess, P. G., Mahowald, N. M., Painter, T. H., Ramanathan, V., and Rasch, P. J.: Springtime warming and reduced snow cover from carbonaceous particles,
Atmos. Chem. Phys., 9, 2481-2497, doi:10.5194/acp-9-24812009, 2009.

Forster, C., Wandinger, U., Wotawa, G., James, P., Mattis, I., Althausen, D., Simmonds, P., O’Doherty, S., Jennings, S. G., Kleefeld, C., Schneider, J., Trickl, T., Kreipl, S., Jäger, H., and Stohl A.: Transport of boreal forest fire emissions from Canada to Europe, J. Geophys. Res., 106, 22887-22906, 2001.

Friedl, M. A., McIver, D. K., Hodges, J. C. F., Zhang, X. Y., Muchoney, D., Strahler, A. H., Woodcock, C. E., Gopal, S., Schneider, A., Cooper, A., Baccini, A., Gao, F., and Schaaf, C.: Global land cover mapping from MODIS: Algorithms and early results, Remote Sens. Environ., 83, 287-302, 2002.

Fromm, M., Bevilacqua, R., Servranckx, R., Rosen, J., Thayer, J. P., Herman, J., and Larko D.: Pyro-cumulonimbus injection of smoke to the stratosphere: Observations and impact of a super blowup in northwestern Canada on 3-4 August 1998, J. Geophys. Res., 110, D08205, doi:10.1029/2004JD005350, 2005.

Garrett, T. J. and Zhao C.: Increased Arctic cloud longwave emissivity associated with pollution from mid latitudes, Nature, 440, 787-789, 2006.

GFMC: Reports on fire smoke pollution in Europe generated by wildland fires in the Russian Federation, available at: http://www.fire.uni-freiburg.de/media/2006/05/news_ 20060518_uk.htm; http://www.fire.uni-freiburg.de/media/ 2006/08/news_20060825_fin.htm; http://www.fire.uni-freiburg. de/media/2006/06/news_20060608_fi.htm; http://www.fire uni-freiburg.de/media/2006/06/news_20060608_fi4.htm; http://www.fire.uni-freiburg.de/media/2006/06/news_

20060608_fi3.htm; http://www.fire.uni-freiburg.de/media/ 2006/06/news_20060608_fi2.htm; http://www.fire.uni-freiburg. de/GFMCnew/2006/05/0501/20060501_ru.htm (last access: 28 September 2014), 2006.

Gong, S. L., Zhao, T. L., Sharma, S., Toom-Sauntry, D., Lavoue, D., Zhang, X. B., Leaitch, W. R., and Barrie, L.: Identification of trends and inter-annual variability of sulphate and black carbon in the Canadian High Arctic: 1981 to 2007, J. Geophys. Res.Atmos., 115, D07305, doi:10.1029/2009JD012943, 2010.

Granier, C., Bessagnet, B., Bond, T., D’Angiola, A., van der Gon, H. D., Frost, G. J., Heil, A., Kaiser, J. W., Kinne, S., Klimont, Z., Kloster, S., Lamarque, J.-F., Liousse, C., Masui, T., Meleux, F., Mieville, A., Ohara, T., Raut, J. C., Riahi, K., Schultz, M. G., Smith, S. J., Thompson, A., van Aardenne, J., van der Werf, G. R., and van Vuuren, D. P.: Evolution of anthropogenic and biomass burning emissions of air pollutants at global and regional scales during the 1980-2010 period, Climatic Change, 109, 163-190, 2011.

Hansen, J. and Nazarenko L.: Soot climate forcing via snow and ice albedos, Proc. Natl. Acad. Sci. USA, 101, 423-428, 2004.

Hao, W. M., Bondarenko, O. O., Zibtsev, S., and Hutton, D.: Vegetation fires, smoke emissions, and dispersion of radionuclides in the Chernobyl exclusion zone, in: Wildland Fires and Air Pollution, Dev. Environ. Sci., vol. 8, edited by: Bytnerowicz, A., Arbaugh, M. J., Riebau, A. R., and Andersen, C., Elsevier, Amsterdam, chap. 12, 265-276, 2009.

Hao, W. M., Petkov, A., Nordgren, B. L., Silverstein, R. P., Corley, R. E., Urbanski, S. P., Evangeliou, N., Balkanski, Y., and Kinder, B.: Daily black carbon emissions from fires in Northern Eurasia from 2002 to 2013, Geosci. Model Dev. Discuss., doi:10.5194/gmd-2016-89, in review, 2016. 
Hauglustaine, D. A., Hourdin, F., Walters, S., Jourdain, L., Filiberti, M.-A., Larmarque, J.-F., and Holland, E. A.: Interactive chemistry in the Laboratoire de Météorologie Dynamique general circulation model: description and background tropospheric chemistry evaluation, J. Geophys. Res., 109, D04314, doi:10.1029/2003JD003957, 2004.

Hirdman, D., Sodemann, H., Eckhardt, S., Burkhart, J. F., Jefferson, A., Mefford, T., Quinn, P. K., Sharma, S., Ström, J., and Stohl, A.: Source identification of short-lived air pollutants in the Arctic using statistical analysis of measurement data and particle dispersion model output, Atmos. Chem. Phys., 10, 669-693, doi:10.5194/acp-10-669-2010, 2010a.

Hirdman, D., Burkhart, J. F., Sodemann, H., Eckhardt, S., Jefferson, A., Quinn, P. K., Sharma, S., Ström, J., and Stohl, A.: Longterm trends of black carbon and sulphate aerosol in the Arctic: changes in atmospheric transport and source region emissions, Atmos. Chem. Phys., 10, 9351-9368, doi:10.5194/acp-10-93512010, 2010b.

Hourdin, F. and Issartel, J. P.: Sub-surface nuclear tests monitoring through the CTBT xenon network, Geophys. Res. Lett., 27, 2245-2248, 2000.

Hourdin, F., Musat, I., Bony, S., Braconnot, P., Codron, F., Dufresne, J.-L., Fairhead, L., Filiberti, M.-A., Friedlingstein, P., Grandpeix, J.-Y., Krinner, G., Levan, P., Li, Z.-X., and Lott, F.: The LMDZ4 general circulation model: climate performance and sensitivity to parametrized physics with emphasis on tropical convection, Clim. Dynam., 27, 787-813, 2006.

Huang, L., Gong, S. L., Sharma, S., Lavoué, D., and Jia, C. Q.: A trajectory analysis of atmospheric transport of black carbon aerosols to Canadian high Arctic in winter and spring (19902005), Atmos. Chem. Phys., 10, 5065-5073, doi:10.5194/acp10-5065-2010, 2010.

IFFN: Recent Trends of Forest Fires in Central Asia and Opportunities for Regional Cooperation in Forest Fire Management, available at: http://www.fire.uni-freiburg.de/iffn/iffn_31/ 16b-IFFN-31-Central-Asia-2.pdf (last access: 28 September 2014), 2004.

Jiao, C., Flanner, M. G., Balkanski, Y., Bauer, S. E., Bellouin, N., Berntsen, T. K., Bian, H., Carslaw, K. S., Chin, M., De Luca, N., Diehl, T., Ghan, S. J., Iversen, T., Kirkevåg, A., Koch, D., Liu, X., Mann, G. W., Penner, J. E., Pitari, G., Schulz, M., Seland, Ø., Skeie, R. B., Steenrod, S. D., Stier, P., Takemura, T., Tsigaridis, K., van Noije, T., Yun, Y., and Zhang, K.: An AeroCom assessment of black carbon in Arctic snow and sea ice, Atmos. Chem. Phys., 14, 2399-2417, doi:10.5194/acp-14-2399-2014, 2014.

Jost, H.-J., Drdla, K., Stohl, A., Pfister, L., Loewenstein, M., Lopez, J. P., Hudson, P. K., Murphy, D. M., Cziczo, D. J., Fromm, M. , Bui, T. P., Dean-Day, J., Gerbig, C., Mahoney, M. J., Richard, E. C., Spichtinger, N., Pittman, J. V., Weinstock, E. M., Wilson, J. C., and Xueref, I.: In-situ observations of mid-latitude forest fire plumes deep in the stratosphere, Geophys. Res. Lett. 31, L11101, doi:10.1029/2003GL019253, 2004.

Klonecki, A., Hess, P., Emmons, L., Smith, L., Orlando, J., and Blake, D.: Seasonal changes in the transport of pollutants into the Arctic troposphere - model study, J. Geophys. Res., 108, 8367, doi:10.1029/2002JD002199, 2003.

Koch, D. and Hansen, J.: Distant origins of Arctic black carbon: A Goddard Institute for Space Studies ModelE experiment, J. Geophys. Res., 110, D04204, doi:10.1029/2004JD005296, 2005.
Krinner, G., Viovy, N., de Noblet-Ducoudre, N., Ogee, J., Polcher, J., Friedlingstein, P., Ciais, P., Sitch, S., and Prentice, I. C.: A dynamic global vegetation model for studies of the coupled atmosphere-biosphere system, Global Biogeochem. Cy., 19, GB1015, doi:10.1029/2003GB002199, 2005.

Lamarque, J.-F., Bond, T. C., Eyring, V., Granier, C., Heil, A., Klimont, Z., Lee, D., Liousse, C., Mieville, A., Owen, B., Schultz, M. G., Shindell, D., Smith, S. J., Stehfest, E., Van Aardenne, J., Cooper, O. R., Kainuma, M., Mahowald, N., McConnell, J. R., Naik, V., Riahi, K., and van Vuuren, D. P.: Historical (1850-2000) gridded anthropogenic and biomass burning emissions of reactive gases and aerosols: methodology and application, Atmos. Chem. Phys., 10, 7017-7039, doi:10.5194/acp10-7017-2010, 2010.

Law, K. S. and Stohl, A.: Arctic air pollution: Origins and impacts, Science, 315, 1537-1540, 2007.

Lee, Y. H., Lamarque, J.-F., Flanner, M. G., Jiao, C., Shindell, D. T., Berntsen, T., Bisiaux, M. M., Cao, J., Collins, W. J., Curran, M., Edwards, R., Faluvegi, G., Ghan, S., Horowitz, L. W., McConnell, J. R., Ming, J., Myhre, G., Nagashima, T., Naik, V., Rumbold, S. T., Skeie, R. B., Sudo, K., Takemura, T., Thevenon, F., Xu, B., and Yoon, J.-H.: Evaluation of preindustrial to presentday black carbon and its albedo forcing from Atmospheric Chemistry and Climate Model Intercomparison Project (ACCMIP), Atmos. Chem. Phys., 13, 2607-2634, doi:10.5194/acp13-2607-2013, 2013a.

Lee, Y. H., Lamarque, J.-F., Flanner, M. G., Jiao, C., Shindell, D. T., Berntsen, T., Bisiaux, M. M., Cao, J., Collins, W. J., Curran, M., Edwards, R., Faluvegi, G., Ghan, S., Horowitz, L. W., McConnell, J. R., Ming, J., Myhre, G., Nagashima, T., Naik, V., Rumbold, S. T., Skeie, R. B., Sudo, K., Takemura, T., Thevenon, F., Xu, B., and Yoon, J.-H.: Corrigendum to "Evaluation of preindustrial to present-day black carbon and its albedo forcing from Atmospheric Chemistry and Climate Model Intercomparison Project (ACCMIP)" published in Atmos. Chem. Phys., 13, 2607-2634, 2013, Atmos. Chem. Phys., 13, 6553-6554, doi:10.5194/acp-13-6553-2013, 2013 b.

Liu, J., Fan, S., Horowitz, L. W., and Levy, H.: Evaluation of factors controlling long - range transport of black carbon to the Arctic, J. Geophys. Res., 116, D04307, doi:10.1029/2010JD015145, 2011.

Lubin, D. and Vogelmann, A. M.: A climatologically significant aerosol long wave indirect effect in the Arctic, Nature, 439, 453456, 2006.

Myhre, G., Samset, B. H., Schulz, M., Balkanski, Y., Bauer, S., Berntsen, T. K., Bian, H., Bellouin, N., Chin, M., Diehl, T., Easter, R. C., Feichter, J., Ghan, S. J., Hauglustaine, D., Iversen, T., Kinne, S., Kirkevåg, A., Lamarque, J.-F., Lin, G., Liu, X., Lund, M. T., Luo, G., Ma, X., van Noije, T., Penner, J. E., Rasch, P. J., Ruiz, A., Seland, Ø., Skeie, R. B., Stier, P., Takemura, T., Tsigaridis, K., Wang, P., Wang, Z., Xu, L., Yu, H., Yu, F., Yoon, J.-H., Zhang, K., Zhang, H., and Zhou, C.: Radiative forcing of the direct aerosol effect from AeroCom Phase II simulations, Atmos. Chem. Phys., 13, 1853-1877, doi:10.5194/acp-13-18532013, 2013.

Nedelec, P., Thouret, V., Brioude, J., Sauvage, B., Cammas, J.P., and Stohl, A.: Extreme CO concentrations in the upper troposphere over North-East Asia in June 2003 from the insitu MOZAIC aircraft data, Geophys. Res. Lett. 32, L14807, doi:10.1029/2005GL023141, 2005. 
Park, R. J., Jacob, D. J., Palmer, P. I., Clarke, A. D., Weber, R. J., Zondlo, M. A., Eisele, F. L., Bandy, A. R., Thornton, D. C., Sachse, G. W., and Bond, T. C.: Export efficiency of black carbon aerosol in continental outflow: Global implications, J. Geophys. Res., 110, D11205, doi:10.1029/2004JD005432, 2005.

Petzold, A., Ogren, J. A., Fiebig, M., Laj, P., Li, S.-M., Baltensperger, U., Holzer-Popp, T., Kinne, S., Pappalardo, G., Sugimoto, N., Wehrli, C., Wiedensohler, A., and Zhang, X.-Y.: Recommendations for reporting "black carbon" measurements, Atmos. Chem. Phys., 13, 8365-8379, doi:10.5194/acp-13-83652013, 2013.

Quinn, P. K., Shaw, G., Andrews, E., Dutton, E. G., Ruoho-Airola, T., and Gong, S. L.: Arctic haze: current trends and knowledge gaps, Tellus B, 59, 99-114, 2007.

Quinn, P. K., Bates, T. S., Baum, E., Doubleday, N., Fiore, A. M., Flanner, M., Fridlind, A., Garrett, T. J., Koch, D., Menon, S., Shindell, D., Stohl, A., and Warren, S. G.: Short-lived pollutants in the Arctic: their climate impact and possible mitigation strategies, Atmos. Chem. Phys., 8, 1723-1735, doi:10.5194/acp8-1723-2008, 2008.

Samset, B. H., Myhre, G., Herber, A., Kondo, Y., Li, S.-M., Moteki, N., Koike, M., Oshima, N., Schwarz, J. P., Balkanski, Y., Bauer, S. E., Bellouin, N., Berntsen, T. K., Bian, H., Chin, M., Diehl, T., Easter, R. C., Ghan, S. J., Iversen, T., Kirkevåg, A., Lamarque, J.-F., Lin, G., Liu, X., Penner, J. E., Schulz, M., Seland, Ø., Skeie, R. B., Stier, P., Takemura, T., Tsigaridis, K., and Zhang, $\mathrm{K}$.: Modelled black carbon radiative forcing and atmospheric lifetime in AeroCom Phase II constrained by aircraft observations, Atmos. Chem. Phys., 14, 12465-12477, doi:10.5194/acp14-12465-2014, 2014.

Schulz, M.: Constraining Model Estimates of the Aerosol Radiative Forcing, Thèse d'Habilitation à Diriger des Recherches, Université Pierre et Marie Curie, Paris VI, 2007.

Schulz, M., Balkanski, Y., Dulac, F., and Guelle, W.: Role of aerosol size distribution and source location in a three-dimensional simulation of a Saharan dust episode tested against satellite derived optical thickness, J. Geophys. Res., 103, 10579-10592, 1998.

Sharma, S., Andrews, E., Barrie, L. A., Ogren, J. A., and Lavoué D.: Variations and sources of the equivalent black carbon in the high Arctic revealed by long-term observations at Alert and Barrow: 1989-2003, J. Geophys. Res., 111, D14208, doi:10.1029/2005JD006581, 2006.

Sharma, S., Ishizawa, M., Chan, D., Lavoue, D., Andrews, E., Eleftheriadis, K., and Maksyutov, S.: 16 year simulation of Arctic black carbon: transport, source contribution, and sensitivity analysis on deposition, J. Geophys. Res.-Atmos., 118, 943-964, doi:10.1029/2012jd017774, 2013.

Shaw, G. E.: The Arctic haze phenomenon, B. Am. Meteorol. Soc., 76, 2403-2413, 1995.

Shaw, P. M., Russell, L. M., Jefferson, A., and Quinn, P. K.: Arctic organic aerosol measurements show particles from mixed combustion in spring haze and from frost flowers in winter, Geophys. Res. Lett., 37, L10803, doi:10.1029/2010GL042831, 2010.

Shindell, D. T., Chin, M., Dentener, F., Doherty, R. M., Faluvegi, G., Fiore, A. M., Hess, P., Koch, D. M., MacKenzie, I. A., Sanderson, M. G., Schultz, M. G., Schulz, M., Stevenson, D. S., Teich, H., Textor, C., Wild, O., Bergmann, D. J., Bey, I., Bian, H., Cuvelier, C., Duncan, B. N., Folberth, G., Horowitz, L. W., Jonson, J., Kaminski, J. W., Marmer, E., Park, R., Pringle, K. J., Schroeder,
S., Szopa, S., Takemura, T., Zeng, G., Keating, T. J., and Zuber, A.: A multi-model assessment of pollution transport to the Arctic, Atmos. Chem. Phys., 8, 5353-5372, doi:10.5194/acp-85353-2008, 2008.

Sirois, A. and Barrie, L. A.: Arctic lower tropospheric aerosol trends and composition at Alert, Canada: 1980-1995, J. Geophys. Res., 104, 11599-11618, 1999.

Sofiev, M., Vankevich, R., Ermakova, T., and Hakkarainen, J.: Global mapping of maximum emission heights and resulting vertical profiles of wildfire emissions, Atmos. Chem. Phys., 13, 7039-7052, doi:10.5194/acp-13-7039-2013, 2013.

Stohl, A.: Characteristics of atmospheric transport into the Arctic troposphere, J. Geophys. Res., 111, D11306, doi:10.1029/2005JD006888, 2006.

Stohl, A., Eckhardt, S., Forster, C., James, P., and Spichtinger, N.: On the pathways and timescales of intercontinental air pollution transport, J. Geophys. Res., 107, 4684, 2002.

Stohl, A., Berg, T., Burkhart, J. F., Fjǽraa, A. M., Forster, C., Herber, A., Hov, Ø., Lunder, C., McMillan, W. W., Oltmans, S., Shiobara, M., Simpson, D., Solberg, S., Stebel, K., Ström, J., Tørseth, K., Treffeisen, R., Virkkunen, K., and Yttri, K. E.: Arctic smoke - record high air pollution levels in the European Arctic due to agricultural fires in Eastern Europe in spring 2006, Atmos. Chem. Phys., 7, 511-534, doi:10.5194/acp-7-511-2007, 2007.

Stohl, A., Klimont, Z., Eckhardt, S., Kupiainen, K., Shevchenko, V. P., Kopeikin, V. M., and Novigatsky, A. N.: Black carbon in the Arctic: the underestimated role of gas flaring and residential combustion emissions, Atmos. Chem. Phys., 13, 8833-8855, doi:10.5194/acp-13-8833-2013, 2013.

Textor, C., Schulz, M., Guibert, S., Kinne, S., Balkanski, Y., Bauer, S., Berntsen, T., Berglen, T., Boucher, O., Chin, M., Dentener, F., Diehl, T., Easter, R., Feichter, H., Fillmore, D., Ghan, S., Ginoux, P., Gong, S., Grini, A., Hendricks, J., Horowitz, L., Huang, P., Isaksen, I., Iversen, I., Kloster, S., Koch, D., Kirkevåg, A., Kristjansson, J. E., Krol, M., Lauer, A., Lamarque, J. F., Liu, X., Montanaro, V., Myhre, G., Penner, J., Pitari, G., Reddy, S., Seland, Ø., Stier, P., Takemura, T., and Tie, X.: Analysis and quantification of the diversities of aerosol life cycles within AeroCom, Atmos. Chem. Phys., 6, 1777-1813, doi:10.5194/acp-6-1777-2006, 2006.

Waibel, A. E., Fischer, H., Wienhol, F. G., Siegmund, P. C., Lee, B., Ström, J., Lelieveld, J., and Crutzen, P. J.: Highly elevated carbon monoxide concentrations in the upper troposphere and lowermost stratosphere at northern midlatitudes during the STREAM II summer campaign in 1994, Chemosphere, 1, 233- 248, 1999.

Wang, P. K.: Moisture plumes above thunderstorm anvils and their contributions to cross-tropopause transport of water vapor in midlatitudes, J. Geophys. Res., 108, 4194 doi:10.1029/2002JD002581, 2003.

Wang, Q., Jacob, D. J., Spackman, J. R., Perring, A. E., Schwarz, J. P., Moteki, N., Marais, E. A., Ge, C., Wang, J., and Barrett, S. R. H.: Global budget and radiative forcing of black carbon aerosol: Constraints from pole-to-pole (HIPPO) observations across the Pacific, J. Geophys. Res. Atmos., 119, 195-206, doi:10.1002/2013JD020824, 2014.

Wang, R., Tao, S., Balkanski, Y., Ciais, P., Boucher, O., Liu, J., Piao, S., Shen, H., Vuolo, M. R., Valari, M., Chen, H., Chen, Y., Cozic, A., Huang, Y., Li, B., Li, W., Shen, G., Wang, B., and Zhang, Y.: Exposure to ambient black carbon derived from a unique inven- 
tory and high resolution model, Proc. Natl. Acad. Sci. USA, 14, 2459-2463, 2014.

Warneke, C., Bahreini, R., Brioude, J., Brock, C. A., de Gouw, J. A., Fahey, D. W., Froyd, K. D., Holloway, J. S., Middlebrook, A., Miller, L., Montzka, S., Murphy, D. M., Peischl, J., Ryerson, T. B., Schwarz, J. P., Spackman, J. R., and Veres, P.: Biomass burning in Siberia and Kazakhstan as an important source for haze over the Alaskan Arctic in April 2008, Geophys. Res. Lett., 36, L02813, doi:10.1029/2008GL036194, 2009.
Warneke, C., Froyd, K. D., Brioude, J., Bahreini, R., Brock, C. A., Cozic, J., de Gouw, J. A., Fahey, D. W., Ferrare, R., Holloway, J. S., Middlebrook, A. M., Miller, L., Montzka, S., Schwarz, J. P., Sodemann, H., Spackman, J. R., and Stohl, A.: An important contribution to springtime Arctic aerosol from biomass burning in Russia, Geophys. Res. Lett., 37, L01801, doi:10.1029/2009GL041816, 2010.

Wotawa, G. and Trainer M.: The influence of Canadian forest fires on pollutant concentrations in the United States, Science, 288, 324-328, 2000. 